\title{
Review Article \\ Distribution and Fate of Military Explosives and Propellants in Soil: A Review
}

\begin{abstract}
John Pichtel
Natural Resources and Environmental Management, Ball State University, Muncie, IN 47306, USA

Correspondence should be addressed to John Pichtel, jpichtel@bsu.edu

Received 30 November 2011; Revised 26 February 2012; Accepted 19 March 2012

Academic Editor: Jeffrey L. Howard

Copyright () 2012 John Pichtel. This is an open access article distributed under the Creative Commons Attribution License, which permits unrestricted use, distribution, and reproduction in any medium, provided the original work is properly cited.

Energetic materials comprise both explosives and propellants. When released to the biosphere, energetics are xenobiotic contaminants which pose toxic hazards to ecosystems, humans, and other biota. Soils worldwide are contaminated by energetic materials from manufacturing operations; military conflict; military training activities at firing and impact ranges; and open burning/open detonation (OB/OD) of obsolete munitions. Energetic materials undergo varying degrees of chemical and biochemical transformation depending on the compounds involved and environmental factors. This paper addresses the occurrence of energetic materials in soils including a discussion of their fates after contact with soil. Emphasis is placed on the explosives 2,4,6-trinitrotoluene (TNT), hexahydro-1,3,5-trinitro-1,3,5-triazine (RDX), and octahydro-1,3,5,7-tetranitro1,3,5,7-tetrazocine (HMX), and the propellant ingredients nitroglycerin (NG), nitroguanidine (NQ), nitrocellulose (NC), 2,4dinitrotoluene (2,4-DNT), and perchlorate.
\end{abstract}

\section{Introduction}

Energetic compounds, defined as the active chemical components of explosives and propellants, are necessary both for peaceful (e.g., demolition and mining) and military purposes. Commonly used military energetic compounds include the explosives 2,4,6-trinitrotoluene (TNT), hexahydro-1,3,5-trinitro-1,3,5-triazine (RDX), and octahydro1,3,5,7-tetranitro-1,3,5,7-tetrazocine (HMX) [1]. Nitroglycerin (NG), nitroguanidine (NQ), nitrocellulose (NC), 2,4dinitrotoluene (DNT), and various perchlorate formulations are employed in missile, rocket, and gun propellants [2, $3]$. The chemical structures of these compounds appear in Figure 1.

As a result of military activities and due to improper management and disposal practices many energetic substances and their by-products have contaminated environments to levels that threaten the health of humans, livestock, wildlife, and ecosystems. In humans TNT is associated with abnormal liver function and anemia, and both TNT and RDX have been classified as potential human carcinogens $[4,5]$. TNT toxicity has been demonstrated using earthworm reproduction tests [6], and studies with Vibrio fischeri have established TNT as being "very toxic" to aquatic organisms [7]. Mutagenicity studies have been carried out using TNT and its metabolites on Salmonella strains and mammalian cell lines [8-11]. TNT was found to be mutagenic, with some metabolites more so than the TNT itself.

The effects of RDX on mammals are generally characterized by convulsions. Deaths in rats were associated with congestion in the gastrointestinal tract and lungs $[12,13]$ (oral rat $\mathrm{LD}_{50}=0.07-0.12 \mathrm{~g} / \mathrm{kg}$ ) [14]. Factory employees in Europe and the US have suffered convulsions, unconsciousness, vertigo, and vomiting after RDX exposure [15]. Information is limited concerning health effects of HMX [16]. The USEPA has established lifetime exposure drinking water health advisory limits for TNT, RDX, and HMX at 2.0, 2.0, and $400 \mu \mathrm{g} / \mathrm{L}$, respectively $[17,18]$.

Acute exposure to NG can cause headaches, nausea, convulsions, cyanosis, circulatory collapse, or death $[19,20]$. Chronic exposure may result in severe headaches, hallucinations, and skin rashes [21]. Perchlorate adversely affects human health by interfering with iodine uptake in the thyroid gland [22]. 
<smiles>Cc1c([N+](=O)[O-])cc([N+](=O)[O-])cc1[N+](=O)[O-]</smiles>

(a)

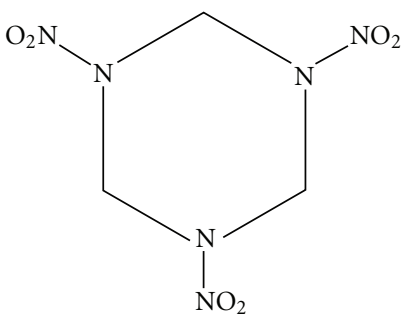

(b)<smiles>O=[N+]([O-])N1CN([N+](=O)[O-])CN([N+](=O)[O-])CN([N+](=O)[O-])C1</smiles>

(c)<smiles>O=[N+]([O-])OCC(CO[N+](=O)[O-])O[N+](=O)[O-]</smiles>

(d)

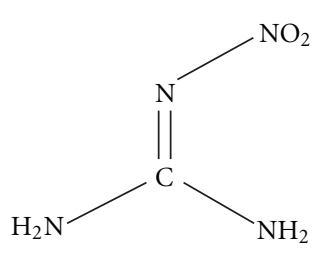

(e)

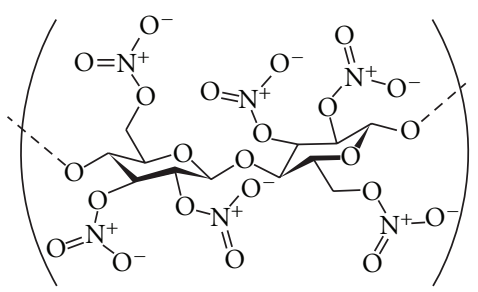

(f)<smiles>Cc1ccc([N+](=O)[O-])cc1[N+](=O)[O-]</smiles>

(g)<smiles>[O-][Cl+3]([O-])([O-])[O-]</smiles>

(h)

FIGURE 1: Chemical structures of energetic compounds: (a) 2,4,6-trinitrotoluene (TNT); (b) hexahydro-1,3,5-trinitro-1,3,5-triazine (RDX); (c) octahydro-1,3,5,7-tetranitro-1,3,5,7-terazocine (HMX); (d) nitroglycerin (NG); (e) nitroguanidine (NQ); (f) nitrocellulose (NC); (g) 2,4-dinitrotoluene (DNT); (h) the perchlorate anion.

Energetic compounds may enter the soil environment via numerous avenues including [23-28] the following:

(i) ammunition production facilities, for example, wastewater lagoons, filtration pits;

(ii) packing or warehouse facilities;

(iii) waste disposal and destruction facilities, for example, open dumps, burn pits, incinerators;

(iv) weapons firing ranges;

(v) weapon impact areas.

Soil contamination by energetics at manufacturing sites, conflict areas, and military ranges is an international concern. In the US alone, thousands of military sites are listed as contaminated by energetic compounds [27, 29]. Approximately 50 million acres are affected by bombing and other training activities [30-32]. An even greater number of contaminated sites may exist in Europe and Asia [33]. Significant public health emergencies resulting from soil contamination have launched demands by local citizenry for remediation measures [34]. During the past two decades an increased environmental awareness has compelled military agencies in the US, Canada, and many European and Asian nations to identify sites of energetics contamination and to evaluate the impacts of military activities on the quality of soil, groundwater, and surface water.

\section{Types of Energetic Materials}

Energetic compounds are chemicals that, when exposed to physical or chemical stimuli, decompose extremely rapidly with the evolution of energy in the form of flame, heat, and light. In addition, rapid liberation of heat causes the gaseous products of the reaction (e.g., $\mathrm{N}_{2}, \mathrm{CO}_{2}, \mathrm{H}_{2} \mathrm{O}$ ) to expand and generate high pressures $[33,35-37]$.

2.1. Explosives. Explosives are classified as primary, secondary, or tertiary based on their susceptibility to initiation. Primary explosives are highly sensitive to initiation and include silver azide, lead styphnate, and mercury fulminate. Primary explosives are often used to initiate secondary explosives in a so-called firing train [35]. Common secondary explosives include TNT, RDX, HMX (Table 1, Figure 1), and 
TABLE 1: Composition of common military energetic materials (adapted from $[36,38,39]$ ).

\begin{tabular}{|c|c|}
\hline Name & Composition \\
\hline \multicolumn{2}{|l|}{ Secondary explosives } \\
\hline Amatex & TNT, ammonium nitrate, RDX \\
\hline Ammonal & TNT, ammonium nitrate, aluminium \\
\hline Anatols & TNT, ammonium nitrate \\
\hline Baratol & TNT, barium nitrate \\
\hline C-4 & RDX (91\%), plasticizer (9\%) \\
\hline Composition A & RDX (91\%), wax (9\%) \\
\hline Composition B & RDX (60\%), TNT (39\%), wax (1\%) \\
\hline Cyclotol & RDX, TNT \\
\hline Explosive D & Ammonium picrate, picric acid \\
\hline HTA-3 & HMX, TNT, aluminium \\
\hline Minol & TNT, ammonium nitrate, aluminium \\
\hline Octol & HMX (70\%-75\%), TNT (25\%-30\%) \\
\hline Pentolite & Ammonium picrate, TNT \\
\hline Tetrytol & Tetryl, TNT \\
\hline Torpex & RDX, TNT, aluminium \\
\hline Tritonal & TNT (80\%), aluminium (20\%) \\
\hline \multicolumn{2}{|l|}{ Propellants } \\
\hline Single-base smokeless powder (M1; M6; M10) & NC, 2,4-DNT; NC, 2,4-DNT; NC, diphenylamine \\
\hline Double-base smokeless powder (M2, M5, M8) & NC, 2,4-DNT; NC, 2,4-DNT; NC, diphenylamine \\
\hline Triple-base smokeless powder (M30, M31) & NC, NG, NQ, ethyl centralite \\
\hline
\end{tabular}

tetryl (N-methyl-2-4-6-trinitrophenylnitramine). The energetic compounds most commonly used in military explosives include TNT, RDX, and HMX. Their environmental fate will be addressed in this paper. Tertiary explosives, also termed blasting agents, are so insensitive to shock that they cannot be detonated by reasonable quantities of primary explosive and instead require a secondary explosive. A common tertiary explosive is a physical mixture of ammonium nitrate and fuel oil.

Organic secondary explosives can be further divided into nitroaromatics, nitramines, and nitrate esters. Nitroaromatics, which include TNT, tetryl, and ammonium picrate, contain $\mathrm{NO}_{2}$ groups bonded to carbon atoms on the aromatic ring. Nitramines contain $\mathrm{NO}_{2}$ groups bonded to nitrogen present within an alicyclic ring, for example, RDX and HMX; nitrate esters contain $\mathrm{NO}_{2}$ groups bonded to an oxygen atom attached to an aliphatic carbon, for example, nitroglycerin.

In addition to the infusion of specialized compounds, an explosive formulation may contain impurities or decomposition by-products. For example, TNT may contain dinitrotoluene and trinitrotoluene isomers $[38,40]$, and HMX may occur as an impurity in RDX [41].

2.1.1. TNT. TNT was first used on a significant scale during World War I. It is one of the most common bulk explosives in use today both in military ordnance and in mining and quarrying operations. TNT is used as a booster for highexplosive munitions. It is used alone and in mixtures with other energetic compounds (e.g., RDX and HMX) in explosive formulations including amatol, pentolite, torpex, tritonal, picratol, and others (Table 1) [42].

TNT is chemically and thermally stable, has a low melting point, and is amenable for melt casting [36]. TNT is popular in the military and industry because of its insensitivity to shock and friction, which reduces the risk of accidental detonation [35]. The TNT molecule is slightly soluble in water and has a low vapor pressure and Henry's law constant (Table 2). The octanol : water partitioning coefficient of TNT $\left(\log K_{\mathrm{ow}}=1.86\right)$ indicates that dissolved TNT will not sorb strongly to soils and therefore may be mobile in the biosphere $[1,36,37]$.

2-amino-4,6-dinitrotoluene (2-A-4,6-DNT) and 4amino-2,6-dinitrotoluene (4-A-2,6-DNT) are generated in the biosphere from biotic transformation of TNT nitro groups to amino groups $[43,44]$. Both amino dinitrotoluene isomers are relatively nonvolatile and have solubilities of 17 and $36 \mathrm{mg} / \mathrm{L}$, respectively. Amino dinitrotoluenes have low octanol:water partitioning coefficients $\left(\log K_{\mathrm{ow}}\right.$ of 2.8 and 2.6); however, they are known to bind covalently to soil organic and mineral components $[1,36]$.

2.1.2. RDX. RDX is a highly stable nitramine compound. It is typically used in mixtures with other explosives [35]. RDX is slightly soluble in water $\left(56.4 \mathrm{mg} / \mathrm{L}\right.$ at $\left.25^{\circ} \mathrm{C}\right)$ and has a low vapor pressure (Table 2 ). RDX will not readily volatilize from aqueous solution (Henry's law constant $=6.3 \times 10^{-8}$ atm$\left.\mathrm{m}^{3} \mathrm{~mol}^{-1}\right)[1]$ and will not sorb strongly to soil $\left(K_{\mathrm{ow}}=0.90\right)$ [36]. 
2.1.3. HMX. HMX is used as burster charges for artillery shells [45] and as a component of plastic explosives. HMX has also been used as an ingredient of solid fuel rocket propellants and to implode plutonium-239 in nuclear weapons [46, 47].

The HMX molecule is of low volatility, has a water solubility of $4.5 \mathrm{mg} / \mathrm{L}$ and an octanol : water partitioning coefficient of 0.16 (Table 2) [48]. Dissolved HMX does not readily sorb to soil and therefore may be mobile in the biosphere $[3,37]$.

2.2. Propellants. Solid propellants for guns, artillery, and mortars comprise low-explosive materials formulated to burn at a controlled rate and produce gases that propel rockets or accelerate projectiles from guns [39, 49]. The primary component of gun, artillery, and mortar propellant formulations is commonly a nitro-containing organic chemical such as nitrocellulose (NC) often combined with other energetic compounds such as nitroglycerin (NG), nitroguanidine (NQ), or dinitrotoluenes (DNT) [2, 37]. Solid propellants containing $\mathrm{NC}$ are divided into three classes based on presence of added energetics (Table 1). Single-base propellants contain $\mathrm{NC}$ as the sole energetic material. Double-base propellants contain NC impregnated with an organic nitrate such as NG. Triple-base propellants include $\mathrm{NC}$ and $\mathrm{NG}$ in combination with nitroguanidine (NQ) $[36,49,50]$. Additional ingredients include compounds that modify burn rate, binders or plasticizers that facilitate loading the propellant into the shell, and compounds that enhance propellant stability during storage [40].

2.2.1. Nitroglycerin. Nitroglycerin (Figure 1) is a nitrate ester widely used by the military for the manufacture of propellants and dynamite. Its solubility ranges from 1,250 to $1,950 \mathrm{mg} / \mathrm{L}$, and it has a $\log K_{\text {ow }}$ of $1.62[51,52]$. Nitroglycerin was found to be extremely sensitive to slight shocks; to address this concern Alfred Nobel in 1866 absorbed nitroglycerin (75\%) in kieselguhr (diatomaceous earth) (25\%) to create dynamite. Kieselguhr, an inactive ingredient, stabilizes nitroglycerin and makes dynamite a much safer explosive to handle. Nitroglycerin is often encountered in soils of live-fire military training ranges, particularly near firing points [39].

2.2.2. Nitroguanidine. Nitroguanidine (Figure 1) melts at $450^{\circ} \mathrm{F}\left(232^{\circ} \mathrm{C}\right)$ and decomposes at $480^{\circ} \mathrm{F}\left(250^{\circ} \mathrm{C}\right)$. Its solubility at $25^{\circ} \mathrm{C}$ is $4.4 \mathrm{~g} / \mathrm{L}$, and its vapor pressure is $1.6 \times$ $10^{-4}$ bar [53]. Nitroguanidine is not flammable and is an extremely low-sensitivity explosive; however, its detonation velocity is high. In triple-base smokeless powder NQ reduces the propellant's flame temperature without loss of chamber pressure. Nitroguanidine is typically used in large-bore guns where barrel erosion and flash are key concerns [39].

2.2.3. Nitrocellulose. Nitrocellulose (Figure 1) is composed of polymerized cellulose chains in which nitrate esters replace most hydroxyl functions. Other compounds are incorporated to control the physical properties of the propellant, its burning rate, and long-term stability [39]. Nitrocellulose is insoluble in water [50].

2.2.4. Dinitrotoluenes. 2,4-Dinitrotoluene (DNT) is used in the production of smokeless powders, as a plasticizer in rocket propellants and as a gelatinizing and waterproofing agent $[54,55]$. Both dinitrotoluene isomers $(2,4-\mathrm{DNT}$ and 2,6-DNT) may occur as impurities during manufacture of TNT or may be formed during biotic and abiotic transformation of TNT $[3,19] .2,4-$ and 2,6-DNT have similar chemical properties. They have low aqueous solubility, are relatively nonvolatile, and have octanol: water partitioning coefficients of 1.98 and 2.02, respectively [36]. Both are listed as US EPA priority pollutants [56]. 2,4-DNT is often detected in surface soils of live-fire military training ranges $[57,58]$.

2.2.5. Perchlorate. Perchlorate $\left(\mathrm{ClO}_{4}{ }^{-}\right)$(Figure 1$)$ is a highly oxidized $(+7)$ chlorine oxyanion which, when reacted with $\mathrm{NH}_{4}{ }^{+}, \mathrm{K}^{+}$and $\mathrm{Na}^{+}$, serves as an oxidizer in solid propellants for rockets, missiles, explosives, and pyrotechnics [59-62]. Composite propellants, used in many rocket motors, typically consist of an organic fuel (such as ammonium picrate) combined with an inorganic oxidizer (commonly perchlorate, powdered aluminum, or barium nitrate) and an organic-binding agent $[49,50]$. In a 2001 DOD survey of weapons systems containing perchlorate, 259 different munitions and related items such as fuses, flares, illumination rounds, simulators, and grenades, as well as 41 missile systems were listed [63].

Most perchlorate salts are highly soluble in water [43]; sodium perchlorate has a solubility of about $2 \mathrm{~kg} / \mathrm{L}$ [64]. The periodic replacement and use of solid propellant have resulted in the discharge of more than 15.9 million $\mathrm{kg}$ of perchlorate salts into the environment $[62,64]$.

\section{Soil Contamination Episodes}

Substantial data is available regarding concentrations of energetic materials at sites adversely affected by manufacturing operations [19,87-91]. Additionally, in recent years detailed information regarding military activities and levels of energetics residues at firing ranges has become available [2-4, 68, 92] (Figure 2, Table 3).

3.1. Contamination from Manufacturing Operations. Sources of soil contamination include explosives machining, casting and curing, improper storage practices, and improper disposal of contaminated wastewaters [23, 93]. The Pantex Plant (TX) was used during World War II by the US Army for loading conventional ammunition shells and bombs. Current operations include development, testing, and fabrication of high explosive components $[90,94]$. The plant's solid waste management unit is contaminated with TNT, RDX, and HMX. Concentrations are highest at $10 \mathrm{~m}$ depth and continue downward in places to $85 \mathrm{~m}$. Plumes containing explosives have been detected offsite with the potential for leaching into the Ogallala aquifer, the region's primary 


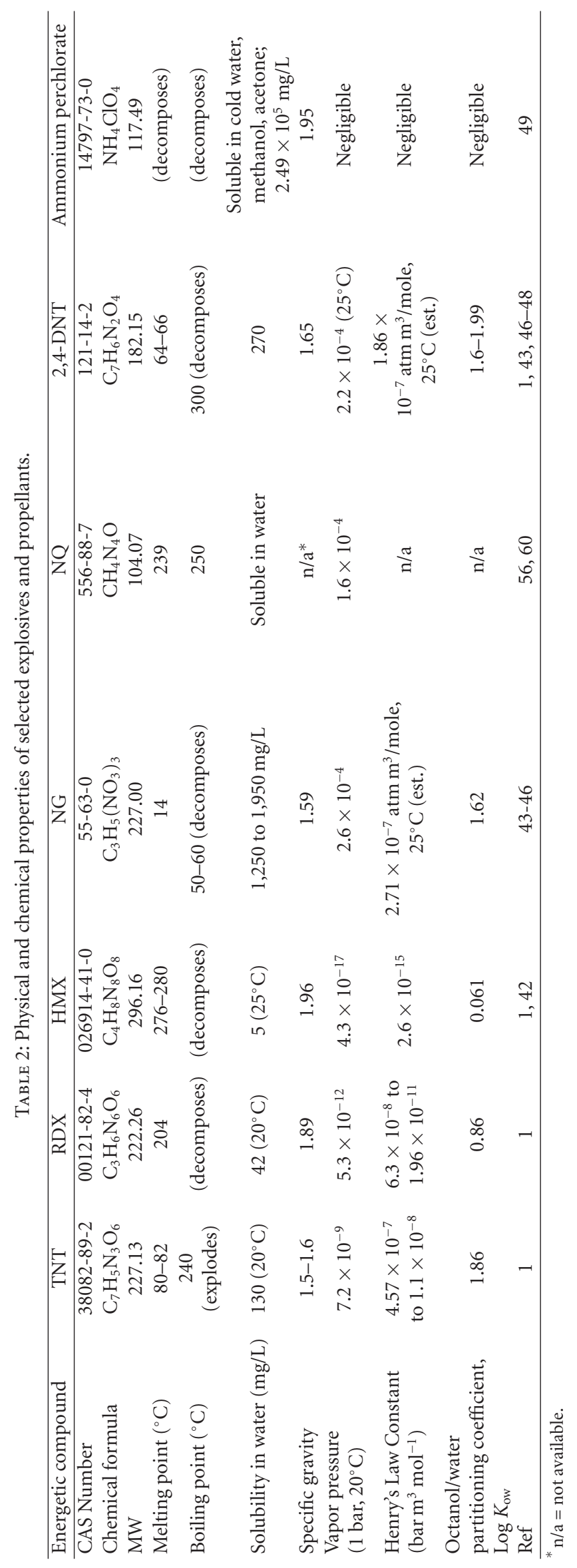




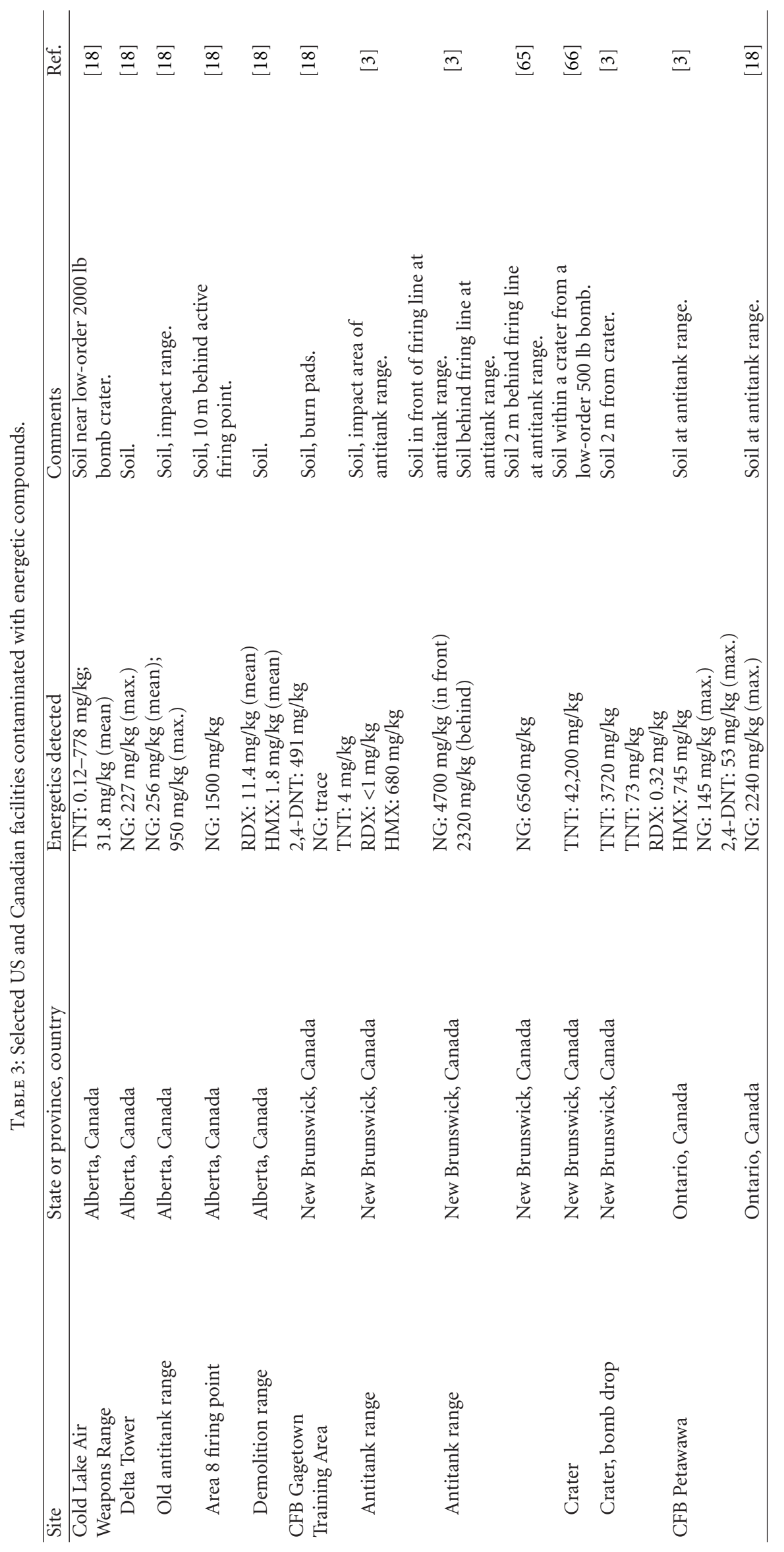




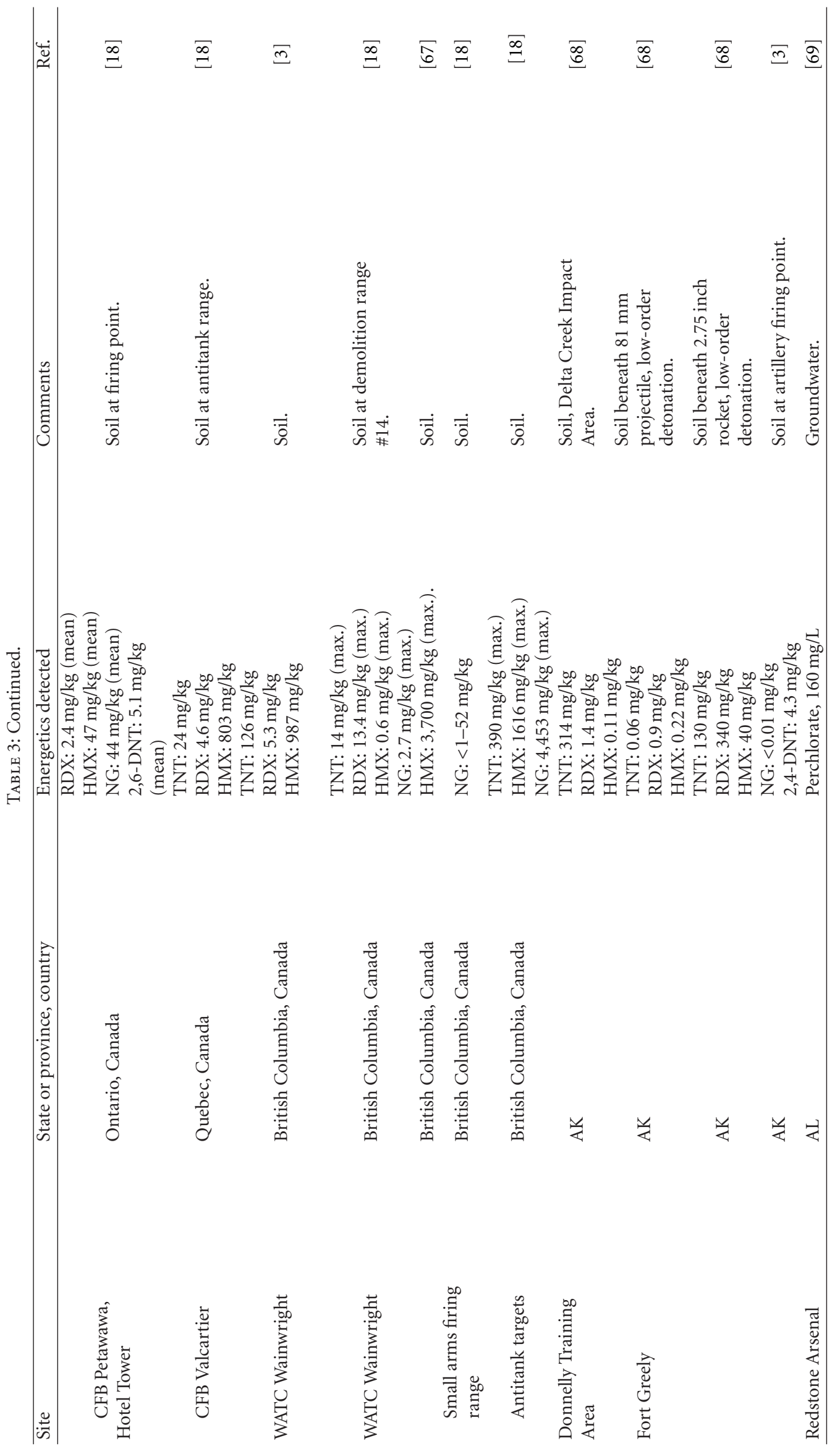




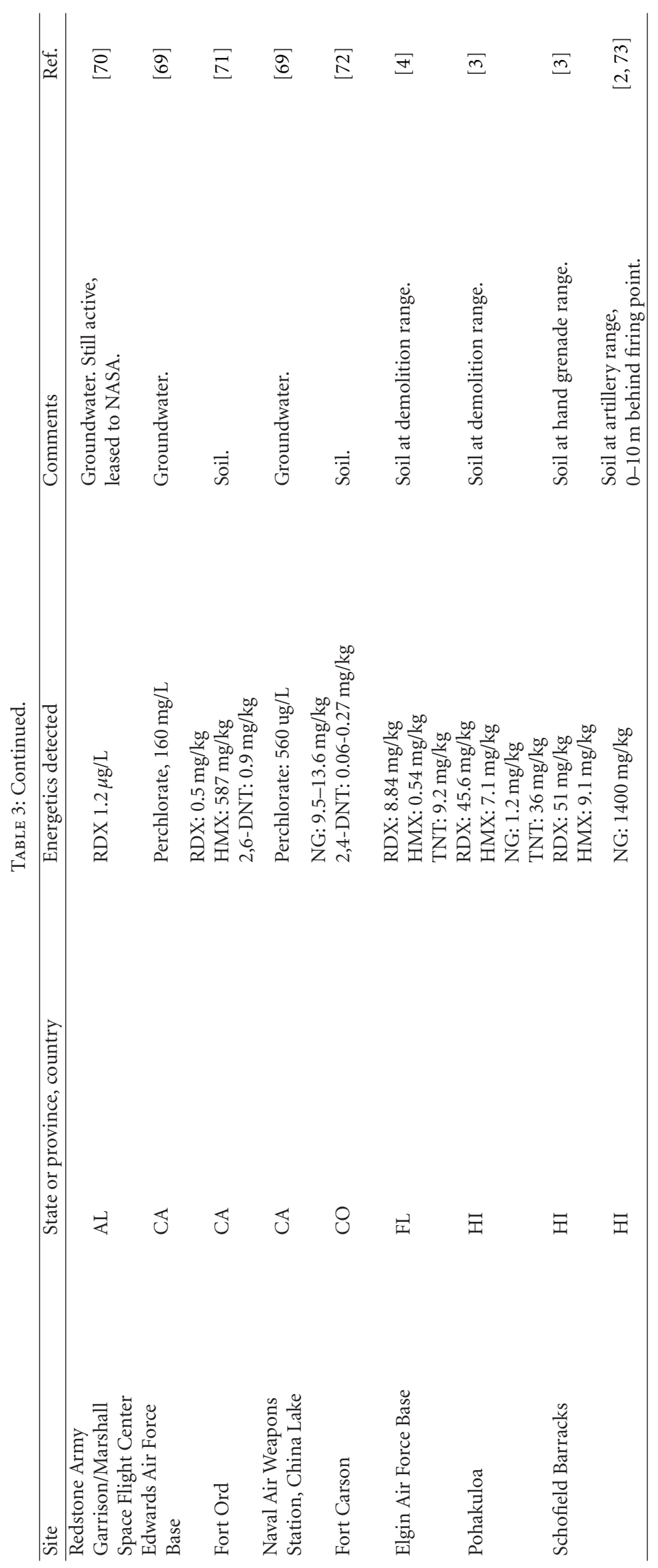




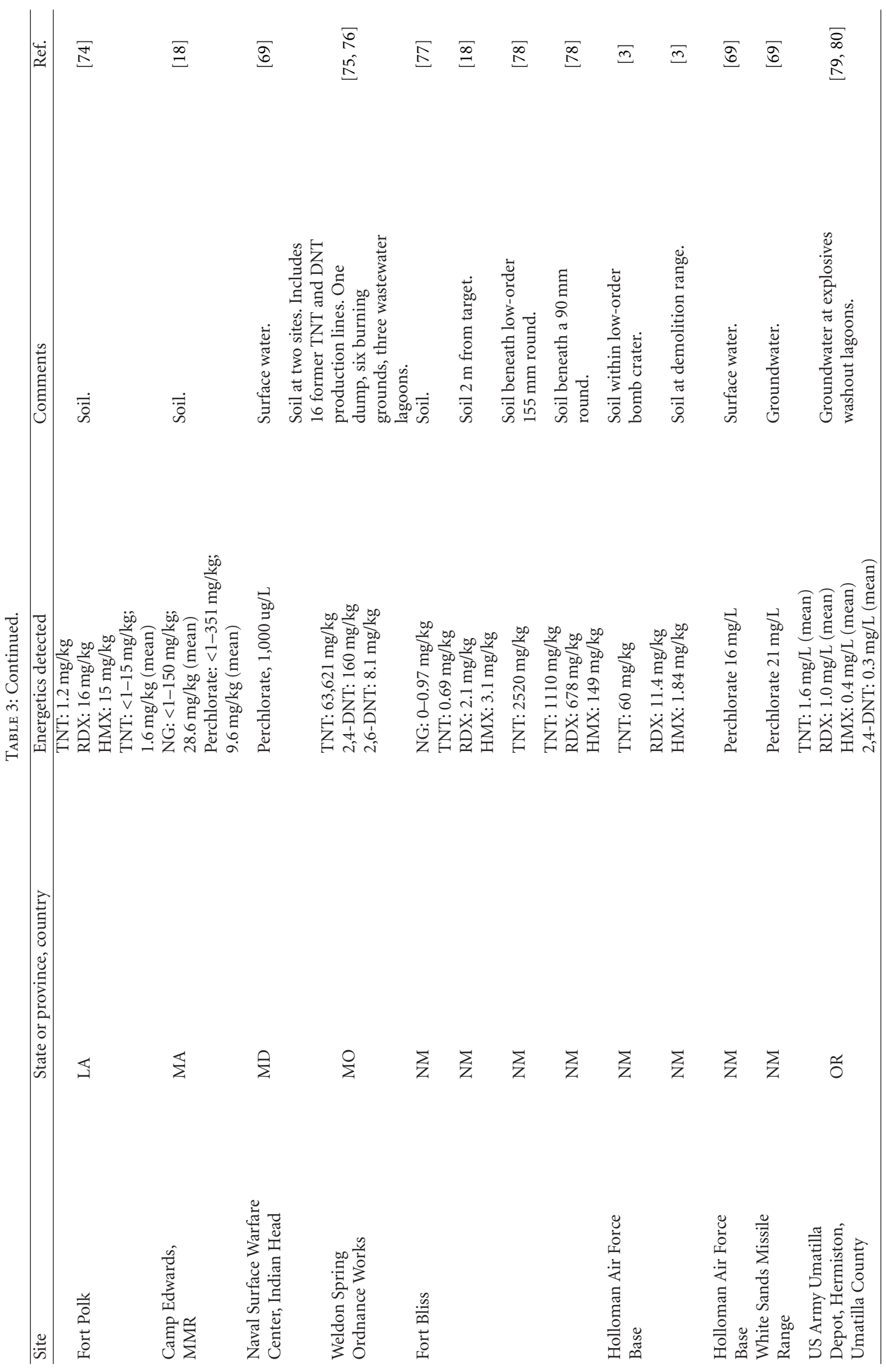




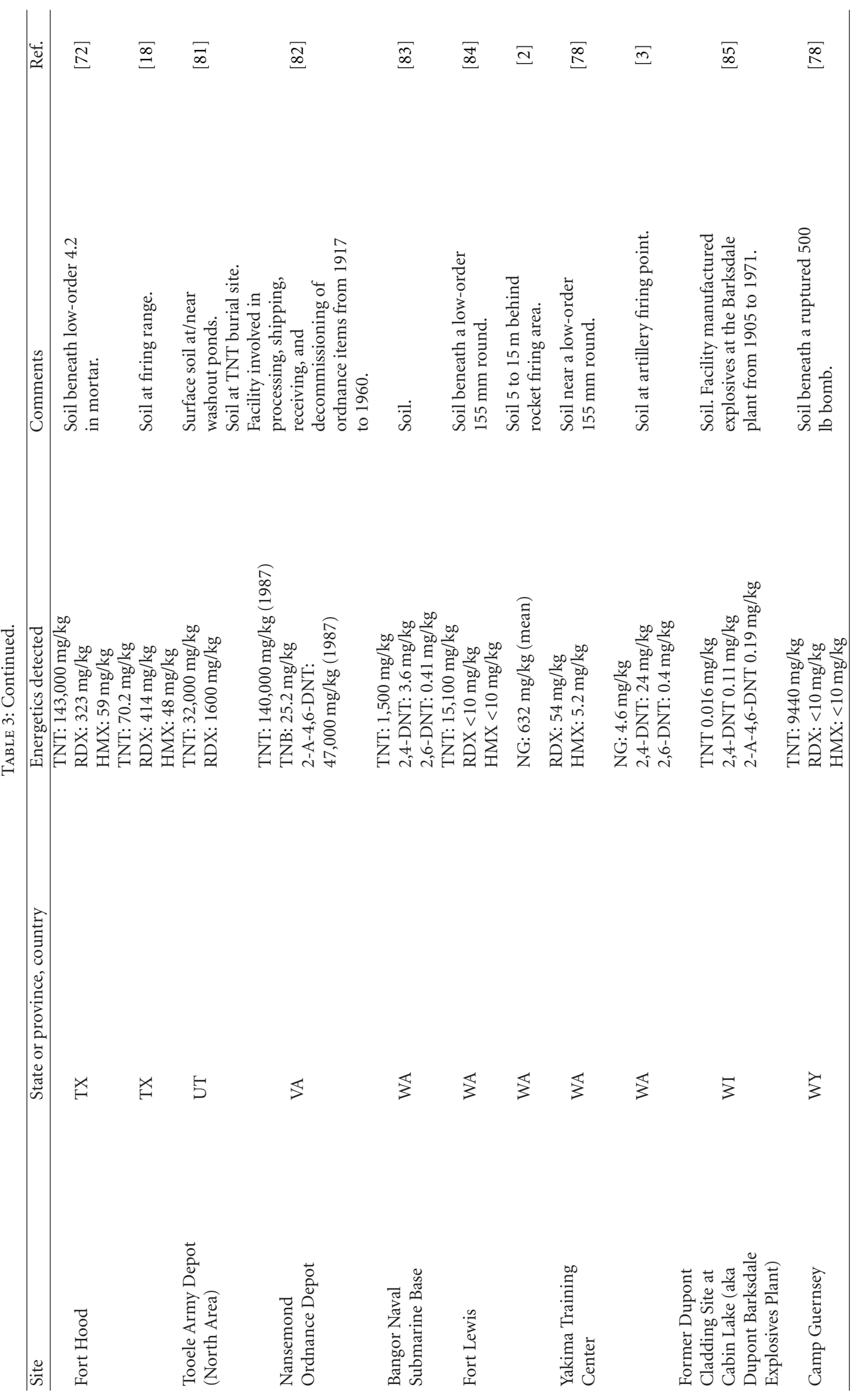




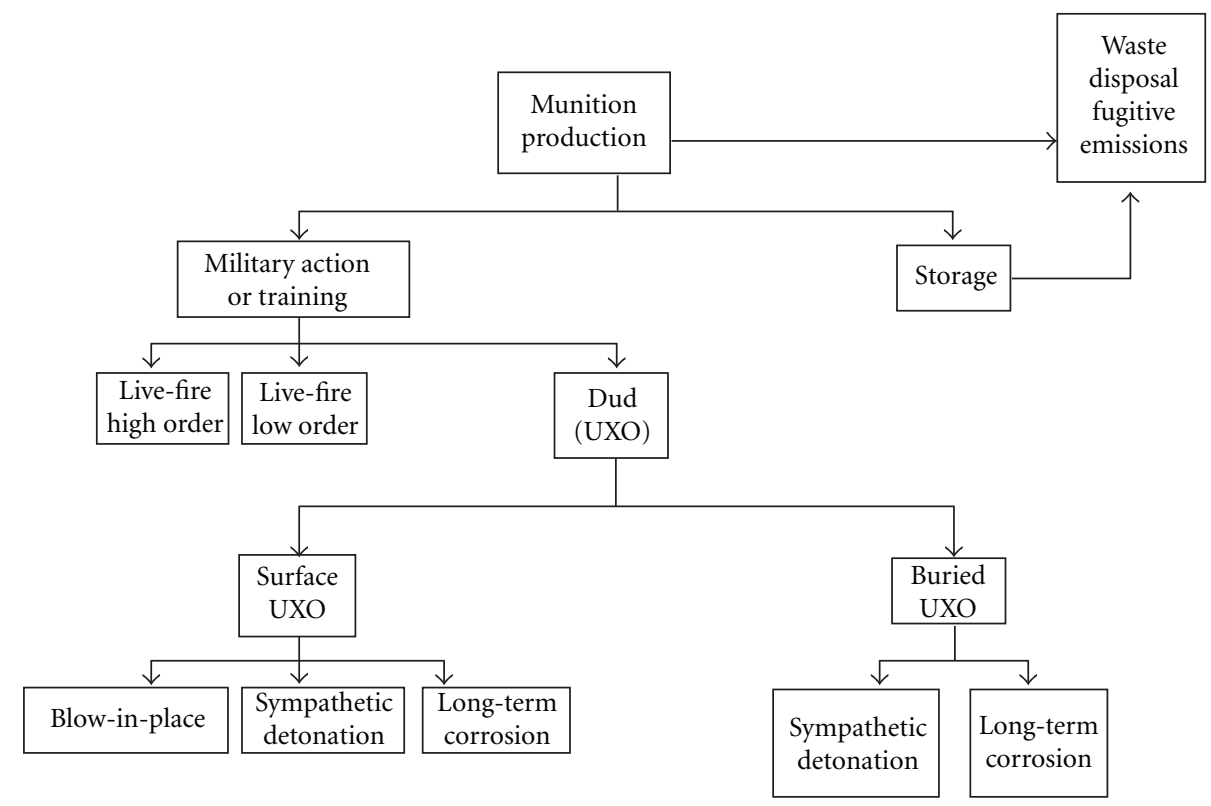

Figure 2: Possible fates of explosives. (Adapted from $[33,86]$ ).

source of drinking water [33]. The site was placed on the National Priorities List (NPL) in 1994 [87].

For decades the US military had used unlined evaporation/percolation lagoons for disposal of wastewaters from manufacturing, demilitarization, and load, assemble, and pack (LAP) operations. Many explosives have subsequently accumulated at the surfaces of lagoons, sometimes at concentrations in the percent range $[28,94]$. These areas are a significant concern relative to long-term soil and groundwater contamination as well as for the potential for accidental detonation [18].

Outfalls from explosives manufacturing at Los Alamos National Laboratory (NM) discharged TNT-, RDX-, and HMX-contaminated waters onto a mesa from 1944 to 1996. Newman et al. [95] detected residues released through burial or dispersion of solid-phase explosives near the Los Alamos site. The majority, however, was released through wastewater discharges in surface runoff or into unlined ponds. Explosives concentrations in surface soils ranged to more than $20 \%$ $\mathrm{w} / \mathrm{w}$, and concentrations in surface waters measured up to $800 \mu \mathrm{g} / \mathrm{L}[95,96]$.

From the 1940s through 1977 more than four billion pounds of explosives, primarily TNT and tetryl, were manufactured in the MFG Area at the Joliet Army Ammunition Plant (IL) [88]. The MFG Area contains $139,500 \mathrm{yd}^{3}$ of soil contaminated with explosives, primarily TNT, tetryl, and DNT. An additional $13,500 \mathrm{yd}^{3}$ of soil are enriched with metals, primarily $\mathrm{Pb}$, and $15,700 \mathrm{yd}^{3}$ contain both explosives and metals. A number of groundwater plumes contaminated with explosives, volatile organic compounds, and/or metals have been identified.

In the Joliet Plant LAP Area 12,400 $\mathrm{yd}^{3}$ of soil are contaminated with TNT, RDX, and HMX, and $17,500 \mathrm{yd}^{3}$ contain both metals and explosives. In addition, several areas contain unexploded ordnance (UXO). Four separate groundwater plumes contaminated with explosives have been detected [88].

Explosives processing, handling, and storage took place at the Savanna Army Depot (IL) until its closure in 1995. Soils are affected by TNT and RDX as well as metals, pesticides, and polycyclic aromatic hydrocarbons. TNT and RDX, solvents, and petroleum-related contaminants were detected in groundwater [97].

An estimated 100,000 tons of TNT were produced at the former ammunition site WerkTanne in Germany. During manufacturing operations over five million $\mathrm{m}^{3}$ of toxic wastewater were generated. Environmental damage was exacerbated by the destruction of the facility during Allied bombing raids in 1944. This site remains highly polluted today with explosives and their metabolites as well as with polycyclic aromatic hydrocarbons and heavy metals [98].

At the former Explosives Factory Maribyrnong, Victoria, Australia, a 5.5 ton crystalline TNT zone was delineated on a former waste lagoon. A near-pure TNT layer with an average thickness of $3 \mathrm{~cm}$ was located $10-15 \mathrm{~cm}$ below the surface. The TNT contaminant profile in the vadose zone was a result of leaching, recrystallization, sorption, transformation reactions, precipitation of TNT at the water table interface, and aqueous transport [28].

Large-scale disposal of ammonium perchlorate salts from manufacturing operations has resulted in contamination of both groundwater and surface water, particularly in the western United States. Perchlorate has been detected in water supplies of 15 million homes in California, Nevada, and Arizona [99]. It is also known to contaminate the Colorado River, a major source of irrigation water in the southwestern US, which could potentially result in perchlorate uptake by crops $[100,101]$. 


\subsection{Contamination from Military Activities}

3.2.1. UXOs and Low-Order Detonations. A fired munition will experience one of several possible fates. Generally, it will detonate as intended (a "high-order detonation"). However, it may experience a low-order detonation or not explode at all (i.e., a dud). Unexploded ordnance (UXO) refers to explosive, propellant, or chemical-containing munitions that had been armed and fired, yet did not explode due to malfunction [102].

(1) Asia, the Middle East, Africa, and Europe. In 2002 The Viet Nam Ministry of Defense estimated UXO- and landmine-affected land to comprise "approximately 7-8\% of the country." Between 15 and $20 \%$ of UXO and mines from the war are believed to remain [103]. Official sources estimate from 350,000-800,000 tons of war-era ordnance in the soil [104]. The Ministry of Defense states that "three million [antipersonnel] landmines remain in Vietnam's soil" [105]. All provinces are affected as well as major cities. Despite extensive clearance operations in the 1990s, landmines remain a serious problem on the Chinese and Cambodian borders. Many UXOs occur on the Laotian border. Minefields remain from the 1954 Dien Bien Phu campaign against the French, continuing through border conflicts with China and the Khmer Rouge in the 1970s [106].

Approximately 85\% of all landmines contain TNT [107]. Although military grade TNT generally contains about $99 \%$ of 2,4,6-trinitrotoluene, other components occur, including 2,4-DNT, 2,6-DNT, 1,3-dinitrobenzene, and 1,3,5-trinitrobenzene.

More than 580,000 bombing missions were conducted over Laos between 1964 and 1973, with more than 2 million tons of ordnance dropped. This includes more than 270 million cluster submunitions, which are the most common form of UXO remaining. It is estimated that up to $30 \%$ failed to detonate [108]. In Cambodia millions of mortar bombs, rocket-propelled and rifle grenades, artillery shells, cluster bomb submunitions, aircraft bombs, and antipersonnel and antitank mines litter two areas of the country. Only a small percentage of land has been cleared of UXO and mines [109]. Over 60,000 UXO and mine casualties have been recorded since 1979 [110].

A total of 1,215 sites contaminated by UXOs have been identified in Australia, with the majority in West Australia (334 sites), New South Wales (292), and Queensland (269) [111]. All affected sites comprise military training ranges.

Somaliland, Puntland, and Central and Southern Zone (CSZ) contain hundreds of thousands of UXO including grenades, artillery shells, rocket-propelled grenades and mortars. The UXO is amassed at former camps, scattered in the aftermath of attacks on depots, and deposited during battles [112].

Iraq is one of the most energetics-contaminated countries in the world. Affected sites cover an estimated $1,730 \mathrm{~km}^{2}$ and affect 1.6 million people. Contamination includes 20 million mines, numerous UXO sites, and many abandoned munitions sites. Over 50 million cluster bomblets were dropped on Iraqi soil. Landmines are concentrated in Iraqi
Kurdistan, within the major oil infrastructure, and in areas bordering Iran, while UXOs impair areas in the southern and central governorates [113].

It is estimated that southern Lebanon was littered with one million undetonated cluster bombs dropped by Israeli Defense Forces in the last days of the 2006 Israel-Lebanon war $[114,115]$. The Palestinian Occupied Territories are plagued by both UXO and landmines [116]. In 2002 UNICEF concluded that most minefields dating from the 1967 Middle East war were not marked. Israeli military training zones are not fenced, and UXOs are not collected following training exercises. In addition, in most areas of confrontation, Israeli and Palestinian UXOs and improvised explosive devices remain in the ground [117].

During the war between Armenian forces and Azerbaijan (1988-1994), battle lines frequently shifted, leaving Nagorno-Karabakh contaminated with UXO and landmines. The NKR Ministry of Agriculture estimated that 37 million $\mathrm{m}^{2}$ of arable land and 35 million $\mathrm{m}^{2}$ of pasture are affected, and $80,000 \mathrm{~m}^{2}$ of vineyards are unusable [118].

Russian officials have admitted to large-scale use of mines in Chechnya [119]. During 1999-2000 Russian forces deployed antipersonnel mines from airplanes, helicopters, and rockets $[120,121]$. In 2002 it was estimated that Russia had planted approximately three million mines during the Second Chechen War [122]. Throughout 2002 and 2003 Chechen rebels used landmines on an almost daily basis against both Russian and civilian targets. A true assessment of the locations and quantities of mines is difficult given that battle lines constantly changed combined with factors such as natural flooding, limited clearance activities, scavenging and reuse, and ongoing fighting [123].

(2) The United States and Canada. Most UXO occurring in the US and Canada is the result of weapons testing and troop training activities. Land affected by UXO includes active military sites, land transferred to private ownership such as Formerly Used Defence Sites, and land no longer used for military purposes but still under US Government ownership, such as Base Realignment and Closure sites [124].

Originally 2300 sites in the US and overseas US facilities were identified as possible UXO sites. Subsequent investigations have narrowed this number to 1400 sites. The total affected land area comprises some 10 million acres [125]. Some munitions use dates back to the US Civil War and World War I [69, 125]. Estimates for remediation of this acreage have ranged from tens of billions of dollars to more than $\$ 100$ billion [124].

Numerous live-fire and demolition ranges have been studied at US and Canadian military bases for contamination by energetics [2, 3, 18, 27, 39, 65-68, 71, 73, 74, 92, 126, 127]. Affected sites include antitank rocket, hand grenade, rifle grenade, demolition, tank firing, mortar, artillery, C-130 gunship, and bombing ranges. Training is conducted with a range of munitions containing a suite of energetic mixtures.

The primary source of explosive and propellant contamination at live-fire ranges is residues from detonation of military munitions including projectiles (e.g., mortar and 
artillery rounds), grenades, landmines, aerial bombs, and missiles, as well as ordnance demolition charges. Energetic residues at firing points tend to be composed of propellant formulations, and those at impact areas are high explosives in warheads $[3,18,128]$.

Firing points and targets at live-fire ranges are widely spaced; therefore, much of the land is uncontaminated by residues of energetic compounds. A high degree of spatial heterogeneity of residues has been detected $[2,3,92,129$ 132]. Distribution on impact ranges (e.g., from antitank and artillery firing and bomb drops) has been described as randomly distributed point sources [18, 133]. Explosives concentrations spanning five orders of magnitude have been reported in samples located within $3 \mathrm{~m}$ of each other [18, 134].

Most detonations during live-fire testing and training are high-order (i.e., the round performs as designed). When high order detonations of artillery rounds, mortars, and hand grenades occur, most of the explosive is consumed and only a relatively small percentage $\left(10^{-3}\right.$ to $10^{-6}$ percent) of the initial mass is deposited $[2,3,133-135]$. Therefore, high-order detonations do not contribute significantly to the overall residues at firing ranges. As a result of low-order detonations during live-fire training large chunks, fibers, slivers, and soil-size particles $(<2 \mathrm{~mm})$ of the original formulations are dispersed over the soil surface $[135,136]$. The incidence of low-order explosions varies among weapon systems.

Taylor et al. [136] estimated that as much as $2 \%$ of a TNT-filled $155 \mathrm{~mm}$ round remained on the soil surface after a high-order detonation, which is equivalent to $140 \mathrm{~g}$ of explosive residues per round. If the round undergoes a loworder detonation, up to $3 \mathrm{~kg}$ of TNT would be deposited. Pennington et al. [18] noted a trend of increasing residue mass with decreasing energy of detonation.

At Fort Greely, AK, soil was sampled near a 2.75 inch rocket from a low-order detonation. Concentrations of TNT, RDX and HMX were 130, 340 and $40 \mathrm{mg} / \mathrm{kg}$, respectively [68]. At Fort Bliss (NM), soil near a low-order $155 \mathrm{~mm}$ round contained $2520 \mathrm{mg} / \mathrm{kg}$ TNT [78]. TNT concentrations were $143,000 \mathrm{mg} / \mathrm{kg}$ near a low-order 4.2 inch mortar [133]. During environmental investigations at 23 military firing ranges in the US and Canada, concentrations of TNT and RDX from Composition B were often hundreds or thousands of $\mathrm{mg} / \mathrm{kg}$ in soils next to low-order detonations [18]. The bulk charge in US and Canadian army fragmentary munitions is either TNT or Composition B. The formula for Composition B is a $60 \%: 39 \%$ ratio of RDX and TNT, containing $\sim 1 \%$ wax as a binder. However, all weapons-grade RDX contains 8 to $10 \% \mathrm{HMX}$ as an impurity. Therefore, the formula for Composition B is closer to $55.2 \% \mathrm{RDX}, 39 \% \mathrm{TNT}, 4.8 \%$ HMX, and $1 \%$ wax [137].

The most extensively studied US training area is probably Camp Edwards, Massachusetts Military Reservation (MMR), where military activities have taken place since 1938. Nearly 9,500 soil samples and 5,500 groundwater samples have been collected and analyzed for contamination by energetic compounds $[8,18,138-143]$. The energetics most frequently detected include, in order of decreasing frequency, perchlorate, RDX, HMX, the amino transformation products of
TNT, and 2,4-DNT. The MMR occurs on highly permeable soils and experiences abundant rainfall. These conditions create a "worst case" for contamination of groundwater by munitions constituents leaching from surface soils [18]. Primary sources of groundwater contamination were low-order detonation residues in the impact areas around targets and UXO [27].

3.2.2. Residues as a Function of Weapon System. The types and concentrations of energetic compounds present in soil are a function of the type of weapon systems used.

Antitank Ranges. The munitions most commonly fired at anti-tank rocket ranges are $66 \mathrm{~mm}$ M72 Light Antitank Weapons (also known as Light Anti-Armor Weapon or LAW rockets) and $84 \mathrm{~mm}$ AT- 4 rockets. The primary charge in LAW rockets is octol, which is composed of HMX and TNT in a 60:40 ratio. The double-base M72 propellant contains $55 \%$ NC, 35\% NG, $8 \%$ potassium perchlorate, $0.8 \%$ ethyl centralite, and $1.2 \%$ carbon black $[27,128]$. The propellant for the AT-4 is also double base (NC/NG), but the formulation is proprietary [2].

LAW rockets sometimes rupture upon impact without detonating; this is the major source of explosives residues at impact areas of anti-tank ranges [3]. The primary residue detected is HMX with concentrations near targets generally in the hundreds of $\mathrm{mg} / \mathrm{kg}$. TNT, RDX, 4-ADNT, and 2ADNT are often detectable as well, but concentrations are several orders of magnitude lower.

High concentrations of HMX were associated with ruptured LAW rockets at Canadian Force Base (CFB) Valcartier (QC), Western Area Training Center (WATC) Wainwright (BC), CFB Gagetown (NB), and CFB Petawawa (ON), and at US ranges Fort Ord (CA) and Yakima Training Center (WA) $[18,67,83,144]$. Concentrations of HMX near tank targets were as high as $1,640 \mathrm{mg} / \mathrm{kg}$ in surface soils at CFB Valcartier $[67,83]$ and $587 \mathrm{mg} / \mathrm{kg}$ at Fort Ord [71]. Soil concentrations of TNT occurred at levels of about 0.01 that of HMX at both sites.

Thiboutot et al. [67] studied soil contamination at antitank ranges at WATC Wainwright and Canadian Force Ammunition Depot Dundurn. Relatively high levels of HMX were detected in surface soils (up to $3,700 \mathrm{mg} / \mathrm{kg}$ at Wainwright), and much lower concentrations of TNT were found. In soil collected near a ruptured M72 rocket at Yakima Training Center (WA), concentrations of HMX, TNT, and RDX at the $0-0.5 \mathrm{~cm}$ depth measured $10,400,358$, and $46 \mathrm{mg} / \mathrm{kg}$, respectively. Concentrations declined to $49,1.7$, and $1.5 \mathrm{mg} / \mathrm{kg}$ at $6-10 \mathrm{~cm}$ depth [3,78]. At CFB Petawawa HMX and RDX (up to $17 \mathrm{ug} / \mathrm{L}$ ) were detected in groundwater at impact areas [8].

Nitroglycerin residues are common at the firing points of anti-tank rocket ranges due to the use of double-based propellant in M72 rockets. Residues have been deposited at distances up to $100 \mathrm{~m}$ in front of the muzzle [3]. The major deposition of residue, however, is behind the firing line due to back blast. Studies conducted at anti-tank rocket firing points at Yakima Training Center [18, 78], Fort Bliss (TX) 
[77], CFB Gagetown [65, 66], CFB Valcartier [131], and CFB Petawawa [145] indicate highest NG concentrations behind the firing line due to back blast of shoulder-fired rockets. Concentrations at the low percent level are sometimes found in soil up to $25 \mathrm{~m}$ behind the firing line. Nitroglycerin is also found between the firing line and the target, but the concentrations are generally several orders of magnitude lower [128].

At firing points at US and Canadian sites, Pennington et al. [3] found NG to be the primary residue, with soil concentrations in the hundreds or thousands of $\mathrm{mg} / \mathrm{kg}$ at depths from 0 to $25 \mathrm{~m}$. In Fort Lewis (WA), NG concentrations in samples $15-25 \mathrm{~m}, 25-35 \mathrm{~m}, 35-45 \mathrm{~m}$, and $45-55 \mathrm{~m}$ behind the firing line were $175,82.4,13.0$, and $3.36 \mathrm{mg} / \mathrm{kg}$, respectively. At a second firing area the mean concentration $5-15 \mathrm{~m}$ behind the firing line was $936 \mathrm{mg} / \mathrm{kg}$, and $206 \mathrm{mg} / \mathrm{kg}$ for the 15-25 $\mathrm{m}$ zone [2]. Nitroglycerin concentrations 5$15 \mathrm{~m}$ and $15-25 \mathrm{~m}$ behind the firing line at CFB Valcartier were $788 \mathrm{mg} / \mathrm{kg}$ and $339 \mathrm{mg} / \mathrm{kg}$, respectively [131]. At CFB Petawawa $2400 \mathrm{mg} / \mathrm{kg}$ was detected $0-10 \mathrm{~m}$ behind the firing line, and from 10-20 m behind the line it was $380 \mathrm{mg} / \mathrm{kg}$. At a second anti-tank rocket range which had been closed for 30 years, the mean NG concentration in surface soil was $250 \mathrm{mg} / \mathrm{kg}$ [145].

At the Gagetown Training Area HMX predominated at the target, while NG was detected at high levels near the firing line. The order of energetic residue concentrations was HMX > NG > TNT > RDX > 2-ADNT and 4-ADNT [65]. Nitroglycerin concentrations were as high as $6560 \mathrm{mg} / \mathrm{kg}$ at a distance of $2 \mathrm{~m}$ behind the firing line [65] and were detected to a depth of $60 \mathrm{~cm}$. At the front of the firing point at CFB Gagetown Pennington et al. [3] measured the majority of $\mathrm{NG}$ in the top $11 \mathrm{~cm}$ (range of $6.5-11 \mathrm{mg} / \mathrm{kg}$ ). Below $11 \mathrm{~cm}$ concentrations were typically $<1 \mathrm{mg} / \mathrm{kg}$. HMX, TNT, and NG were detected in high concentrations in ponds located in the target area of the range $[18,74]$.

2,4-DNT has been detected near firing positions at Fort Richardson (AK) and Aberdeen Proving Ground (MD) [146, 147]. At the Arnhem anti-tank range (Quebec, Canada), highest perchlorate concentrations were detected in surface soils just behind the firing line. Perchlorate was detected in all analyzed groundwater samples [27].

Artillery Ranges. The major munition systems fired into artillery ranges include $155 \mathrm{~mm}$ howitzers, $105 \mathrm{~mm}$ howitzers, $120 \mathrm{~mm}$ main tank guns, $81 \mathrm{~mm}$ mortars, $60 \mathrm{~mm}$ mortars, and $120 \mathrm{~mm}$ mortars. The explosives used in artillery and mortar warheads are generally either TNT or Composition B, although some older rounds contained tetryl. Bombs dropped in some ranges contain TNT or tritonal (TNT and aluminum), and $40 \mathrm{~mm}$ grenades contain Composition A5 (RDX). Munitions are delivered using single-, double-, and triple-based gun propellants, and rocket and missile propellants [3].

Results of soil analyses from several locations indicate that very low concentrations of explosives residues are widespread at artillery testing and training ranges. In addition, the distribution of energetics residues is spatially very heterogeneous [83].
On artillery ranges at Camp Guernsey (WY), Fort Bliss (NM), Fort Hood (TX), Fort Polk (LA), and Fort Greely (AK), TNT, RDX, and HMX concentrations near targets ranged from nondetectable to $<1 \mathrm{mg} / \mathrm{kg}$ except for low-order detonations, where concentrations were three or four orders of magnitude greater [3, 68, 131, 148]. At artillery and mortar impact areas at Fort Lewis (WA), concentrations of residues associated with high-order detonations were typically $<1 \mu \mathrm{g} / \mathrm{kg}$ [83]. RDX was detected at $<100 \mu \mathrm{g} / \mathrm{kg}$. Analysis of water samples obtained from monitoring wells and seeps that border the artillery range indicated a low level $(<1 \mu \mathrm{g} / \mathrm{L})$ of RDX contamination. In soil collected near a $155 \mathrm{~mm}$ round that had undergone a low-order detonation the TNT concentration was $1.5 \%$. Concentrations were also high in soils collected at 5 and $10 \mathrm{~cm}$ depths [83]. At a 105 $\mathrm{mm}$ howitzer firing point at the Fort Lewis artillery range 2,4-DNT was detected at concentrations as high as $237 \mathrm{mg} / \mathrm{kg}$ in surface soil [83]. Pennington et al. [3] found that a portion of energetics residues occurred as unburned or partially burned propellant fibers of lengths ranging from 0.4 to $7.5 \mathrm{~mm}$. The unburned fibers contained much higher concentrations of 2,4-DNT than did partially burned ones.

At gun and mortar firing points at Camp Edwards, MMR, Clausen et al. [138] detected 2,4-DNT in soil, mostly in the surface to $1 \mathrm{ft}$ depth. Also, 2,6-DNT, diethyl phthalate, $n$-nitrosodiphenylamine, and di-n-butyl phthalate were identified.

Bomb Drops. Air Force ranges have historically measured hundreds of $\mathrm{km}^{2}$ in size, but current training areas are much smaller, generally only tens of hectares. The explosives in US and Canadian Air Force bombs are usually either tritonal (TNT, aluminum powder) or H-6 (TNT, RDX, aluminum powder). Large-mass high explosive detonations are very efficient, dispersing only microgram to milligram quantities of residue when they detonate high order [135]. As with other ordnance, low-order detonations are the major source of residues from bombs [3].

The Cold Lake Air Weapons Range $[55,149]$ has been in use for air-to-ground bomb drops for over 40 years. Soil TNT concentrations at a target ranged from 3 to $408 \mathrm{mg} / \mathrm{kg}$, with a mean value of $86 \mathrm{mg} / \mathrm{kg}$ over a $50 \mathrm{~m}$ radius. Mean concentrations of RDX, HMX, 4-ADNT, 2-ADNT, 2,4-DNT, and trinitrobenzene were $0.27,0.21,0.71,1.2,0.20$, and $0.13 \mathrm{mg} / \mathrm{kg}$, respectively [3]. The main sources of RDX and TNT were low-order detonations and UXO. RDX was the most mobile and persistent contaminant in groundwater, whereas TNT concentrations were higher but degraded more rapidly.

TNT was detected at the highest concentrations in surface and shallow subsurface soil at an impact range at Holloman AFB (NM). RDX was generally below detection limits although trace levels were sometimes detected due to use of C4 to destroy UXO during range maintenance. No evidence of offsite migration of residues was found with depth or in samples collected along an arroyo that drains the impact range [18].

At the Donnelly Training Area (AK) $[3,68]$ residues included TNT (<1-314 mg/kg), RDX (up to $1.4 \mathrm{mg} / \mathrm{kg}$ ), HMX $\quad(<1 \mathrm{mg} / \mathrm{kg}), \quad 2,4-\mathrm{DNT} \quad(<1 \mathrm{mg} / \mathrm{kg})$, and NG 
$(<1 \mathrm{mg} / \mathrm{kg})$. Only four samples had TNT concentrations $>1 \mathrm{mg} / \mathrm{kg}$. One sample collected near a $500 \mathrm{lb}$ bomb partial detonation had a TNT concentration of $17,300 \mathrm{mg} / \mathrm{kg}$ $[3,18]$.

Hand Grenades. The majority of training at US hand grenade ranges is with M67 fragmentation grenades, in which the explosive charge is $185 \mathrm{~g}$ of Composition B. In Canada, training is generally with $\mathrm{C}-13$ fragmentation grenades; however, they have the same specifications as the M67 [3]. The primary energetic residues on grenade ranges are RDX and TNT from Composition B $[128,132]$.

Variability in soil concentrations of energetics may be substantial at grenade ranges. At Fort Lewis (WA) and Fort Richardson (AK), concentrations of explosives-related compounds differed by over two orders of magnitude for samples collected less than $1 \mathrm{~m}$ apart [83].

On grenade ranges at 23 military installations in the US and Canada, RDX concentrations ranged from $<1 \mathrm{mg} / \mathrm{kg}$ to about $50 \mathrm{mg} / \mathrm{kg}$ [3]. HMX concentrations ranged from $<1 \mathrm{mg} / \mathrm{kg}$ to $9.1 \mathrm{mg} / \mathrm{kg}$. In several instances, chunks of the explosive fill were observed near grenade casings, and their inside surfaces were coated with explosive material.

Jenkins et al. [83] sampled grenade impact areas at Fort Lewis (WA) and Fort Richardson (AK). An estimated 6,000 to 7,000 grenades are thrown on the Fort Lewis range each year. RDX was detected in all 96 samples collected at the ranges, from both surface and shallow subsurface (depths as great as $30 \mathrm{~cm}$ at Fort Lewis and $45 \mathrm{~cm}$ at Fort Richardson). Median and maximum concentrations of RDX in surface soils were 1.6 and $51.2 \mathrm{mg} / \mathrm{kg}$ at Fort Lewis and $<1$ and $0.5 \mathrm{mg} / \mathrm{kg}$ at Fort Richardson. Pennington et al. [78] detected TNT and HMX in most soils from grenade ranges, with maximum concentrations of 40.6 and $5.2 \mathrm{mg} / \mathrm{kg}$, respectively. At CFB Petawawa RDX, HMX, and TNT were detected in relatively low concentrations $(<5 \mathrm{mg} / \mathrm{kg})$ [18]. Highest concentrations were typically measured in the top few $\mathrm{cm}$ of soil. Mean concentrations were 10.8 and 12.5 times greater in surface soils than at the $10 \mathrm{~cm}$ depth for RDX and HMX, respectively, and about 49 times greater for TNT in the surface relative to the $10 \mathrm{~cm}$ depth [3].

3.3. Demolition and Disposal. Demolition ranges at military installations are used to destroy munitions that are considered safe to move. Demolition ranges generally measure a few hectares in size [3]. Substantial residues may be dispersed during demolition events, particularly if they result in loworder detonations or if the $\mathrm{C} 4$ does not detonate completely [74]. Some open burning/open detonation $(\mathrm{OB} / \mathrm{OD})$ areas have generated kickout, that is, UXO which is propelled from burn pits when other munitions explode. As a result, some $\mathrm{OB} / \mathrm{OD}$ areas generate higher concentrations of energetic compounds than those found in impact areas. $\mathrm{OB} / \mathrm{OD}$ areas pose an additional concern since many have been used to dispose of industrial wastes such as paints, solvents, lubricants, and fuels. They may therefore contain a much wider array of hazardous chemicals than ranges where only munitions have burned [151].
RDX is the most common energetic compound at demolition ranges, as it is the major component of $\mathrm{C} 4$ demolition explosive. Nitroglycerin and 2,4-DNT are also frequently detected from disposal of excess propellant [2].

RDX and HMX, probably from C4, were detected at a demolition range at Camp Edwards (MMR). At CFB Petawawa a demolition range was contaminated with a suite of explosives and propellants, primarily RDX and HMX [18]. At Elgin AFB (FL) mean concentrations of RDX and HMX in surface soil samples were 8.84 and $0.54 \mathrm{mg} / \mathrm{kg}$, respectively. At Holloman AFB (NM) mean concentrations of RDX and HMX within a $25 \mathrm{~m}$ radius around a demolition crater were 11.4 and $1.84 \mathrm{mg} / \mathrm{kg}$, respectively [3]. At a site of blow-in place of $155 \mathrm{~mm}$ projectiles at Fort Richardson (AK), average recovered residual mass was $14 \mathrm{mg}$ for RDX and $0.84 \mathrm{mg}$ for HMX. No TNT was detected $[18,74]$. Soil from the Louisiana Army Ammunition Plant was contaminated with 10,000, 1,900 , and $900 \mathrm{mg} / \mathrm{kg}$ of TNT, RDX, and HMX, respectively [89]. These levels resulted after incineration of explosivescontaminated soils and sludges. In studies by Jenkins et al. [2], about $1.7 \%$ of the original NG in a propellant formulation remained after unconfined burning.

\section{Environmental Fate of Energetic Materials}

Following entry into the terrestrial environment both abiotic and biotic processes govern the fate of energetic compounds $[36,37]$. The rate and extent of transport and transformation are influenced by the physicochemical properties of the compounds (e.g., solubility, vapor pressure, Henry's law constant), environmental factors (weather conditions, soil properties, $\mathrm{pH}$, redox status), and biological factors (populations of energetics-degrading microorganisms). Processes that influence the environmental fate of explosive compounds may be divided into (1) influences on transport (dissolution, volatilization, adsorption) and (2) influences on transformation (photolysis, hydrolysis, reduction, and biological degradation) [33]. Figure 3 illustrates the major fate and transport pathways for energetic materials.

4.1. Dissolution. Energetic residues often occur on the soil surface as solid particles and chunks resulting from loworder detonation or as partially fragmented UXO. Dissolution in water is the primary mechanism for their transport and dispersion in the biosphere $[3,33]$. Once in solution, a key factor affecting fate and transport is advection [86].

Numerous studies have addressed the dissolution mechanisms of energetic compounds in soil; many, however, have addressed dissolution of individual explosives and propellant formulations [152-157]. Results may have limited applicability for dissolution of residues on soils at impact zones or firing ranges because explosives and propellants are typically formulated with binders, waxes, stabilizers, and other compounds during manufacture. Binders and waxes decrease dissolution rates of individual explosive compounds [158-160]. Dissolution may therefore proceed more slowly than predicted on the basis of solubility of the pure compound [18].

Due to the relatively low aqueous solubility of TNT (130 mg/L), RDX (42 mg/L), and HMX (5 mg/L) (Table 2), 


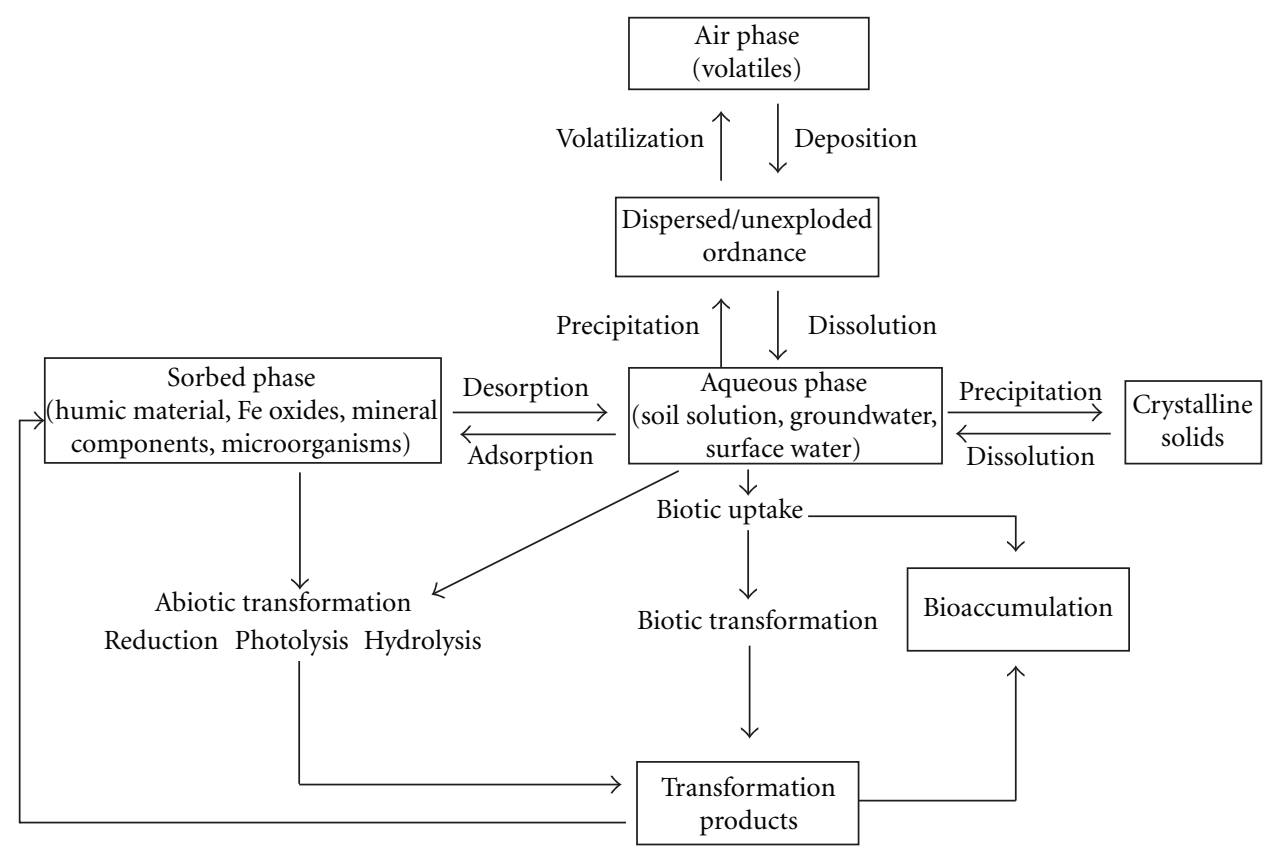

FIgURE 3: Suggested fates of energetic compounds in the environment $[33,36,150]$.

dissolution of solid particles results in continuous release to the local environment over extended periods [33, 160]. In studies performed by Lynch [161] and Lynch et al. [160] using aqueous systems, rate of dissolution followed the order TNT > HMX > RDX. Dissolution rates at $10^{\circ} \mathrm{C}$ were approximately $0.0087,0.0063$, and $0.0013 \mathrm{mg} / \mathrm{min} / \mathrm{cm}^{2}$ for TNT, HMX, and RDX, respectively [36], and rates doubled with every $10^{\circ} \mathrm{C}$ increase in temperature from 3 to $33^{\circ} \mathrm{C}$ $[161,162]$. Rates increased as surface area and mixing rate increased $[3,160,162-165]$ and were independent of $\mathrm{pH}$ (range 4.2-6.2) [162].

Because the aqueous solubility of HMX is low it tends to accumulate on the surface while TNT dissolves. Dissolved HMX does not strongly interact with soils and can migrate through the vadose zone to groundwater. At the Fort Ord (CA) anti-tank rocket range HMX was detectable at concentrations generally $<1 \mathrm{mg} / \mathrm{kg}$ at depths of $120 \mathrm{~cm}$ whereas TNT, RDX, and amino transformation products of TNT were not detected below $15 \mathrm{~cm}$ [71].

At Fort Greely (AK), Fort Bliss (TX), Fort Lewis (WA), Camp Guernsey (WY), Fort Carson (CO) and elsewhere, HMX and RDX penetrated deeper into the soil profile than did TNT [3]. This is consistent with the lower soil/water partition coefficients for HMX and RDX relative to TNT and the susceptibility of TNT to attenuation reactions with soil components (see below) [166-168]. RDX and HMX have been found in groundwater below several training ranges, but TNT has not.

The behavior of 2,4-DNT and 2,6-DNT in soils has been evaluated [148, 158, 169]. Dontsova et al. [158] studied the dissolution of 2,4-DNT and 2,6-DNT from propellant formulation M1 (87.6\% nitrocellulose, 7.3\% 2,4-DNT, $0.57 \%$ 2,6-DNT, $1.06 \%$ diphenylamine, 3.48\% dibutyl phthalate) and their subsequent transport in soil. In propellant formulations 2,4-DNT is impregnated within an insoluble nitrocellulose matrix. M1 dissolution was limited by DNT diffusion from the interior of the pellet, resulting in an exponential decrease in dissolution rate with time. Dissolution rate was higher for 2,4-DNT than for 2,6-DNT.

At US and Canadian artillery ranges the concentration of 2,4-DNT declined from $9.6 \mathrm{mg} / \mathrm{kg}$ in the surface $0-3 \mathrm{~cm}$ to $0.56 \mathrm{mg} / \mathrm{kg}$ at $10-20 \mathrm{~cm}$ depth [3].

$\mathrm{NG}$ is rather mobile in soil in part due to its high solubility (1,250 to $1,950 \mathrm{mg} / \mathrm{L}$ ) (Table 2$)$; however, NG and DNT introduced to soil during military training at small arms ranges did not leach from site soil [170]. The degree to which NG is available for release is a function of the degree of deterioration of the nitrocellulose (NC) encapsulation in the propellant mix $[170,171]$.

As a consequence of its relatively high solubility and negligible partitioning to soil, perchlorate is not expected to persist in soil for any significant length of time. Once in contact with moisture, solid particulate perchlorate rapidly dissolves and is transported [18].

4.2. Volatilization. At ambient temperatures (approximately $0^{\circ}-40^{\circ} \mathrm{C}$ ) most energetic compounds exist as crystalline solids with vapor pressures ranging from $10^{-8}$ to $10^{-17} \mathrm{~atm}$ (Table 2) [36, 37]. Therefore, sublimation (i.e., direct transformation from solid to vapor phase) is insignificant. Likewise, few energetic compounds volatilize from the aqueous phase. Compounds with Henry's law constant $\left(K_{H}\right)$ values $>10^{-5}$ atm- $\mathrm{m}^{3} / \mathrm{mol}$ may volatilize from aqueous solutions. With $K_{H}$ values of $10^{-7}$ to $10^{-15} \mathrm{~atm}-\mathrm{m}^{3} / \mathrm{mol}$, TNT, RDX, HMX, NG, 2,4-DNT, and 2,6-DNT do not 
readily volatilize in the aqueous phase $[36,37]$. Volatilization of energetic compounds is therefore a negligible contribution to the biosphere.

4.3. Adsorption. Adsorption refers to a process by which a dissolved chemical (solute) accumulates at the surface of a particle (sorbent). In the current context, surfaces include those of humic substances, metal oxides and hydroxides, and microorganisms. Sorption reactions may include hydrophobic partitioning, hydrogen bonding, ion exchange, and chemisorption [33, 36, 172, 173]. The extent of partitioning between solute and sorbent is a function of their physicochemical properties as well as environmental conditions $[33,36]$.

TNT is reversibly sorbed by soil $[167,173]$; hydrogen bonding and ion exchange have been suggested as sorption mechanisms between the nitro functional groups and soil colloids [26, 173-175]. Xue et al. [176] determined that soil/water partitioning coefficients $(K d)$ for TNT in surface soils ranged from 2.7 to $3.7 \mathrm{~L} / \mathrm{kg}$. Pennington and Patrick [173] determined $K d$ values to range from 2.3 to $11 \mathrm{~L} / \mathrm{kg}$. In aquifer materials, Pennington et al. [177] measured $K d$ values of $0.04-0.27 \mathrm{~L} / \mathrm{kg}$.

In general, RDX is sorbed less than TNT by soils [150, 167]. Although RDX sorption is minimal, the process is nearly irreversible [174]. Sorption has been described by linear isotherms $[167,178-180]$. Values of $K d$ for RDX have ranged from 0.21 to $0.33 \mathrm{~L} / \mathrm{kg}$ [177], 0.12 to $2.37 \mathrm{~L} / \mathrm{kg}$ [180], and 0.06 to $7.3 \mathrm{~L} / \mathrm{kg}$.

Sorption data for HMX is somewhat varied; however, most authors agree that HMX is less sorbed and more mobile than TNT [181]. Values of $K d$ for HMX have ranged from $0-1.6 \mathrm{~L} / \mathrm{kg}$ (surface soils) [178], 0.09-0.37 L/kg (aquifer material) [177], and $0.12-17.7 \mathrm{~L} / \mathrm{kg}$ (surface soils) [182]. In general, however, HMX adsorption coefficients are $<1 \mathrm{~L} / \mathrm{kg}$ in aquifer materials and within the range of 1 to $18 \mathrm{~L} / \mathrm{kg}$ in surface soils [37].

The number of functional groups on nitroaromatic compounds like TNT influences their sorption capacity [33]. Sheremata et al. [183] determined that $K d$ values increased with an increase in the number of amino groups; that is, sorption of the TNT decomposition product 2,4-diamino6-nitrotoluene (2,4-DANT) was greater than that for 4amino-2,6-dinitrotoluene (4-ADNT) (another decomposition product) which was greater than that for TNT [183].

Clay minerals impart a significant effect on sorption of energetic compounds. Adsorption of TNT onto clays increased in the order montmorillonite $>$ kaolinite [167]. In a montmorillonite clay the $K d$ value for TNT was determined to be $413 \mathrm{~L} / \mathrm{kg}$ [184]. Cattaneo et al. [185] determined $\mathrm{Kd}$ values of 156 and $1.0 \mathrm{~L} / \mathrm{kg}$ for montmorillonite and kaolinite, respectively. Sorption is additionally influenced by the types and amounts of exchangeable cations on the clay surface $[167,186,187]$. Haderlein et al. [167] determined adsorption constants up to $21,500 \mathrm{~L} / \mathrm{kg}$ when $\mathrm{K}^{+}$or $\mathrm{NH}_{4}{ }^{+}$were the principal cations compared to $1.7 \mathrm{~L} / \mathrm{kg}$ when $\mathrm{Al}^{3+}, \mathrm{Ca}^{2+}, \mathrm{Mg}^{2+}$, or $\mathrm{Na}^{+}$was dominant. Brannon et al. [174] demonstrated that saturation of cation exchange sites of aquifer solids with $\mathrm{K}^{+}$ and $\mathrm{NH}_{4}{ }^{+}$resulted in a $9,780 \%$ increase in TNT sorption.
In freshwater environments dominated by $\mathrm{Ca}^{2+}$, sorption of TNT to soil may thus be lower than that observed in a saline environment dominated by $\mathrm{K}^{+}$and $\mathrm{Na}^{+}$. The type of soil or aquifer material and the ionic strength and composition of the water are therefore critical variables in predicting adsorption [37].

Haderlein et al. [167] determined the $K d$ for 2,4DNT reacted with kaolinite, illite, and montmorillonite to be $690,3,650$, and $740 \mathrm{~L} / \mathrm{kg}$, respectively. In contrast, $K d$ values for 2,6-DNT were much lower, with values of 10 , 52 , and $125 \mathrm{~L} / \mathrm{kg}$ for kaolinite, illite, and montmorillonite, respectively. In adsorption experiments using soils from Camp Edwards (MMR) the average $K d$ value for 2,4-DNT was $3.3 \mathrm{~L} / \mathrm{kg}$ [169].

Jenkins et al. [2] found that NG and NQ were retained only slightly in low organic carbon soils. In studies by Brannon et al. [188] NQ partition coefficients were very low, ranging from 0.15 to $0.43 \mathrm{~L} / \mathrm{Kg}$. Haag et al. [189] reported a value of $<0.1 \mathrm{~L} / \mathrm{Kg}$. In soil at small-arms ranges $K d$ values for 2,4-DNT, 2,6-DNT, and NG ranged from 0.1 to 21.3, 0 to 18.2 , and 0 to $7.3 \mathrm{~L} / \mathrm{kg}$, respectively [190]. Mean $K d$ values were $3.2,2.6$, and $0.9 \mathrm{~L} / \mathrm{kg}$, respectively. Soil properties (e.g., organic carbon content, cation exchange capacity, clay content) imparted a significant effect on $K d$. Desorption experiments revealed that a portion of these propellants were irreversibly bound [170]. The lower adsorption coefficient of 2,6-DNT compared to 2,4-DNT in clays is attributed to the steric hindrance of the $\mathrm{NO}_{3}$ group in the ortho position [158].

Sorption of perchlorate to soil is affected by $\mathrm{pH}$ and ionic strength. Sorption is negligible in sandy soil under most conditions, including near-neutral $\mathrm{pH}$ [63]. Perchlorate has been observed to adsorb slightly to variable charge soils in low $\mathrm{pH}$ environments, however [191].

The organic carbon fraction in soil plays a significant role in sorption of energetic compounds. Yamamoto et al. [169] determined that $K d$ values for TNT, RDX, and 2,4DNT were dependent on quantity of soil organic carbon. TNT and 2,4-DNT were more strongly adsorbed compared with RDX. In studies by Brannon and Pennington [37] and Price et al. [181], significantly less RDX than TNT was associated with soil organic matter. Monteil-Rivera et al. [192] determined that soil organic carbon content did not significantly affect HMX sorption. $K d$ coefficients for HMX were 2.5 and $0.7 \mathrm{~L} \mathrm{~kg}^{-1}$ for soil containing $8.4 \%$ and $0.33 \%$ total organic carbon, respectively.

Numerous investigations of the fate of energetic compounds in soils and sediments have used weathered clays, silts, and sands in column and incubation studies $[168,186$, 189, 193]. The behavior of aged mineral surfaces differs markedly from that of newly created surfaces generated by fracturing from detonations, however, Douglas et al. [194] found that fractured soil particles exhibited greater transformation rates for nitroaromatic and nitramine compounds than did weathered soil particles. These results may be caused either by enhanced adsorption to the fractured surfaces or by accelerated transformation processes. 
4.4. Photolysis. Photolysis has been identified as one of the major processes affecting the transformation of energetic compounds in waste streams and surface water bodies [175]. Alteration of a molecule may occur as a consequence of direct absorption of light energy as influenced by wavelength and intensity or via transfer of energy from a photosensitized compound (e.g., peroxide, humic compounds) [36, 195]. Photolytic transformation of energetic compounds in soils presumably occurs only near the soil surface [36].

Phototransformation of TNT results in the formation of nitrobenzenes, benzaldehydes, azoxydicarboxylic acids, and nitrophenols as a result of the oxidation of methyl groups, reduction of nitro groups and dimer formation [33, 175]. Burlinson et al. [196] identified 20 products of TNT photolysis from laboratory irradiation. About 45 to 50 percent of the photodecomposition products of TNT were recovered in solution with the remainder present as insoluble residues, possibly oligomers of azo and azoxy compounds, which were not identified [196].

TNT, alone and as a component of Composition B, generated photolysis products more readily than did RDX [18]. The rate of photolysis over a $16 \mathrm{~h}$ period of irradiation was relatively rapid. Photolysis was faster when TNT was mixed with soil. Results suggest that Composition B photolysis, particularly the TNT component, generates an active mixture of products occurring on solid surfaces before dissolution, and increasing once in solution [18].

Leachate, groundwater, and surface water of former ammunition sites in Germany were analyzed by Godejohann et al. [197]. Several nitrobenzoic acids were identified; 2,4-dinitro-benzoic acid (2,4-DNBA) occurred at $160 \mu \mathrm{g} / \mathrm{kg}$ and 2-amino-4,6-dinitro-benzoic acid (2-A-4,6-DNBA) at $86 \mu \mathrm{g} / \mathrm{kg}$. 4-Amino-nitrobenzoic acid, 2-amino-nitrobenzoic acid, and 2-amino-4-nitrobenzoic acid were detected in drain water samples from a former ammunition plant by Schmidt et al. [198]. Preiss et al. [199] identified several methyl-, amino-, and hydroxynitrobenzoic acids in samples obtained from former German ammunition sites. Hennecke et al. [200] investigated the phototransformation processes of explosives in natural water/sediment systems. System $\mathrm{pH}$ and the presence of natural photosensitizers influenced TNT photolysis rate. The major metabolites identified were 2-A-4,6-DNBA, 4-A-2,6-DNBA, 2,4,6-trinitrobenzoic acid, 1,3,5-trinitrobenzene, and 3,3,5,5-tetranitroazoxybenzene2,2-dicarboxylic acid.

Photolytic processes may transform RDX with the formation of azoxy compounds, $\mathrm{NH}_{3}, \mathrm{NO}_{2}{ }^{-}, \mathrm{NO}_{3}{ }^{-}, \mathrm{N}_{2} \mathrm{O}$, formaldehyde, and $n$-nitroso-methylenediamine [195]. RDX solution reacted in the presence of sunlight for $28 \mathrm{~h}$ until the concentration was not distinguishable from background [201]. After treatment, the solution was found not to be toxic to Ceriodaphnia dubia. Additional products of RDX photolysis included MNX, formate, formamide $\left(\mathrm{CHO}-\mathrm{NH}_{2}\right)$ and urea $\left(\mathrm{CO}\left(\mathrm{NH}_{2}\right)_{2}\right)[202,203]$. Different products may form depending on wavelength of light; however, no mechanisms have been proposed [204].

Photodegradation of DNTs is possible once dissolved in water; however, this mechanism is limited in soils because, similar to TNT $[154,205]$, dissolution rate is expected to be slow [190].

4.5. Hydrolysis. Hydrolysis involves the reaction of a water molecule with the functional group of an organic molecule to form a new carbon-oxygen bond. Amine, amide, nitrile, and carboxylic acid groups are susceptible to hydrolysis. Nitroaromatic compounds, aromatic amines, aldehydes, and benzenes are generally resistant [36].

Hydrolysis of nitroaromatics such as TNT and aromatic amines occur at strongly elevated $\mathrm{pH}$. Such pH levels typically do not occur in the natural environment; however, alkaline hydrolysis has been investigated as a remediation technology for explosives-contaminated soils [33, 36, 206, 207]. Hydrolysis of TNT was demonstrated when soil $\mathrm{pH}$ was $>10[208,209]$. At pH 12 Bajpai et al. [210] observed $>95 \%$ reduction in TNT concentration compared to $25 \%$ reduction at $\mathrm{pH} 11$. A higher $\mathrm{pH}$ was necessary for the destruction of 2A-DNT and 4A-DNT compared to TNT [207].

Hydrolysis of RDX and HMX has been noted under alkaline conditions; however, the rate is extremely slow $[211,212]$. Balakrishnan et al. [213] observed the formation of $\mathrm{NH}_{3}, \mathrm{NO}_{2}, \mathrm{~N}_{2} \mathrm{O}$ and formaldehyde following alkaline hydrolysis of RDX and HMX at $\mathrm{pH}>10$. It was proposed that initial denitration of cyclic nitramines was sufficient to induce ring cleavage and spontaneous decomposition of both compounds.

Transformation products resulting from hydrolysis reactions are similar to those generated during photolysis and biotransformation, and as a result isolating the effects of the hydrolysis process from other reactions is difficult $[36,175$, 213].

4.6. Reduction. Energetic compounds containing nitro functional groups are susceptible to abiotic reduction, with nitro groups being reduced to amino groups [33, 37, 175]. It has been proposed that abiotic reduction requires activation by solid catalysts such as Fe compounds, clay minerals, or organic molecules [33, 214].

Reductive transformation of TNT has been widely documented [150, 172, 175, 177, 215-219]. Laboratory studies have demonstrated the effects of several environmental factors on transformation of TNT including $\mathrm{pH}$, redox status, organic carbon levels, cation exchange capacity, and presence of expandable clays and metallic reducing agents, for example, $\mathrm{Fe}^{2+}$ and $\mathrm{Mn}^{2+}$ [37].

TNT transformations may include reduction of one, two, or all three nitro groups to amines, and coupling of amino transformation products to form dimers [217]. Formation of the two monoamino products, 2-ADNT and 4-ADNT, are energetically favored [220] and are typically observed in TNT-contaminated soils and groundwater.

TNT reduction is significantly greater under anaerobic compared with aerobic conditions [193, 219]. TNT disappeared from the solution phase of slurry tests under highly reduced conditions $(\mathrm{Eh}=-150 \mathrm{mV}$ ) following $1 \mathrm{~d}$ of incubation [193]. At Eh values of $+500 \mathrm{mV}$, TNT disappeared after $4 \mathrm{~d}$. 
TNT, RDX, and HMX reduction by Fe (magnetite, ferrous iron, zero valent iron) has been reported $[181,210,214,221,222]$. The resulting products (e.g., aromatic polyamines, hexahydro-1-nitroso-3,5-dinitro1,3,5-triazine (MNX), hexahydro-1,3-dinitroso-nitro-1,3,5triazine (DNX), and hexahydro-1,3,5-trinitroso-1,3,5triazine (TNX)) may be further metabolized via biotic processes or may become adsorbed to soil colloids.

The rate of TNT transformation by $\mathrm{Fe}^{2+}$ in the presence of montmorillonite or kaolinite increased as $\mathrm{pH}$ increased [223]. Products were primarily mono amino and azoxy compounds; however, mass balances using radiolabeled TNT indicated the presence of unextractable products. Suppression of the abiotic $\mathrm{Fe}^{2+}$ pathway by addition of ethylenediaminetetraacetic acid (EDTA) curbed TNT reduction [223].

Transformation of RDX via formation of mono-, di-, and trinitroso products has been suggested [224, 225] and observed in soil [226]. Reduction leads to destabilization, ring cleavage, and mineralization of RDX under anaerobic conditions [218, 227, 228]. Gregory et al. [214] observed RDX transformation by $\mathrm{Fe}^{2+}$ in aqueous suspensions of magnetite. Sequential reduction resulted in the formation of the nitroso intermediates MNX, DNX, and TNX, and $\mathrm{NH}_{4}{ }^{+}$, $\mathrm{N}_{2} \mathrm{O}$, and formaldehyde end-products. Increased $\mathrm{pH}$ resulted in greater $\mathrm{Fe}^{2+}$ adsorption which subsequently increased RDX transformation rate [214]. The nitroso intermediates of RDX have rarely been observed in field investigations [37]. MNX was detected in groundwater at MMR [18].

Several researchers have demonstrated the potential of zero valent iron (ZVI) for reduction of TNT and RDX in soil or aqueous systems $[172,200,210,214,221,222,229,230]$. A soil slurry containing $6.4 \mathrm{~g} \mathrm{RDX} / \mathrm{kg}$ was reacted over $48 \mathrm{~h}$ with $10 \%$ ZVI to attain RDX levels within EPA recommended limits [230]. The only product detected was $\mathrm{NH}_{4}{ }^{+}$. A study of RDX removal by ZVI in aqueous conditions [172] indicated low levels of MNX, DNX, and TNX. These intermediates disappeared after $96 \mathrm{~h}$, and $\mathrm{NH}_{4}^{+}$was generated throughout the experiment [204].

Few studies regarding HMX reduction have been reported. The rate of HMX transformation by ZVI is significantly less than that of TNT and RDX; however, the application of cationic surfactants, which increase HMX solubility, increases transformation rates [229]. Park et al. [229] demonstrated that ZVI-mediated transformation of HMX may be inhibited in the presence of RDX.

Like many nitrobenzenes [231], 2,4-DNT engages in stepwise two-electron transfer reactions with the generation of nitrosobenzene and $n$-hydroxylaniline intermediates [232] to form aniline.

Although abiotic reduction of energetic compounds is documented for soil and aquifer environments, Juhasz and Naidu [36] state that it is practically impossible to distinguish between biotic and abiotic transformation.

4.7. Biological Transformation. A variety of microorganisms including bacteria and fungi have been demonstrated with the capacity to degrade both explosive and propellant formulations.
4.7.1. TNT. Several TNT biodegradation pathways have been reviewed by Crawford [224], Kalderis et al. [33], and Juhasz and Naidu [36] (Figure 4). The TNT molecule serves as a carbon and/or nitrogen source [43]. TNT degradation may also occur during cometabolism of alternative substrates [33].

Under both aerobic and anaerobic conditions TNT is transformed to the amino derivatives 2-ADNT, 4-ADNT, 2,4-DANT, and 2,6-DANT [43, 44]. Triaminotoluene (TAT) may form under anaerobic conditions [33]. Anaerobic mineralization in the laboratory through TAT to trihydroxytoluenes, polyphenols, $p$-cresol, and acetate has been reported $[224,225]$. These compounds may be further transformed via biotic or abiotic processes. Intermediate products may bind to colloidal surfaces, thereby restricting availability for further reaction [3].

Fungi mineralize TNT via the actions of nonspecific extracellular enzyme systems (lignin peroxidase, manganese peroxidase, laccase). A range of fungi acts upon TNT as a function of species, culture conditions, and substrate $[33,36]$. Various basidiomycetes (e.g., Agaricus aestivalis, Agrocybe praecox, Clitocybeodora) transform TNT, with degree of mineralization ranging from 5 to $15 \%$. Several micromycetous fungi (e.g., Alternaria sp., Aspergillus terreus, Fusarium sp., Mucor mucedo, Penicillum sp., Rhizoctoniai sp.) are known to transform, but not mineralize, TNT [233].

Phanerochaete chrysosporium, the white rot fungus, is the most widely studied TNT-degrading fungal species. Phanerochaete chrysosporium was shown to completely transform TNT [233]; mineralization ranged from 10 to $40 \%$. The initial reaction involves reduction of nitro groups to nitroso-DNT which may be further transformed to 2hydroxylamino-4,6-dinitrotoluene and 4-hydroxylamino2,6-dinitrotoluene (HADNT) and ADNT and DANT. Phanerochaete chrysosporium and other fungal species may subsequently transform ADNT and DANT to azo, azoxy, phenolic, and acetylated by-products [33]. Pasti-Grigsby et al. [234] and Spadaro et al. [235] proposed that the azo derivatives are amenable for mineralization.

4.7.2. $R D X$. Limited aerobic biodegradation of RDX has been observed in soils [236]; however, complete anaerobic biodegradation has been observed under laboratory conditions $[157,211,237]$. RDX is degraded more readily than TNT, particularly under anaerobic conditions $[37,225,238-$ 240]. RDX removal from culture was first observed in 1973 using purple photosynthetic bacteria [236]; anaerobic photosynthetic activity was suggested as being responsible for RDX reduction. More recently, anaerobic RDX degradation was observed using microbial populations from contaminated soil and sewage sludge $[225,241-244]$ and also under nitratereducing [245] and sulfate-reducing [246, 247] conditions. Several cultures required between one week and two months to degrade RDX concentrations ranging from $0.015 \mathrm{mM}$ to $0.17 \mathrm{mM}$. The most rapid degradation of RDX using anaerobic sludge reported $90 \%$ removal of $0.27 \mathrm{mM}$ RDX within $2 \mathrm{~d}$ [248]. 


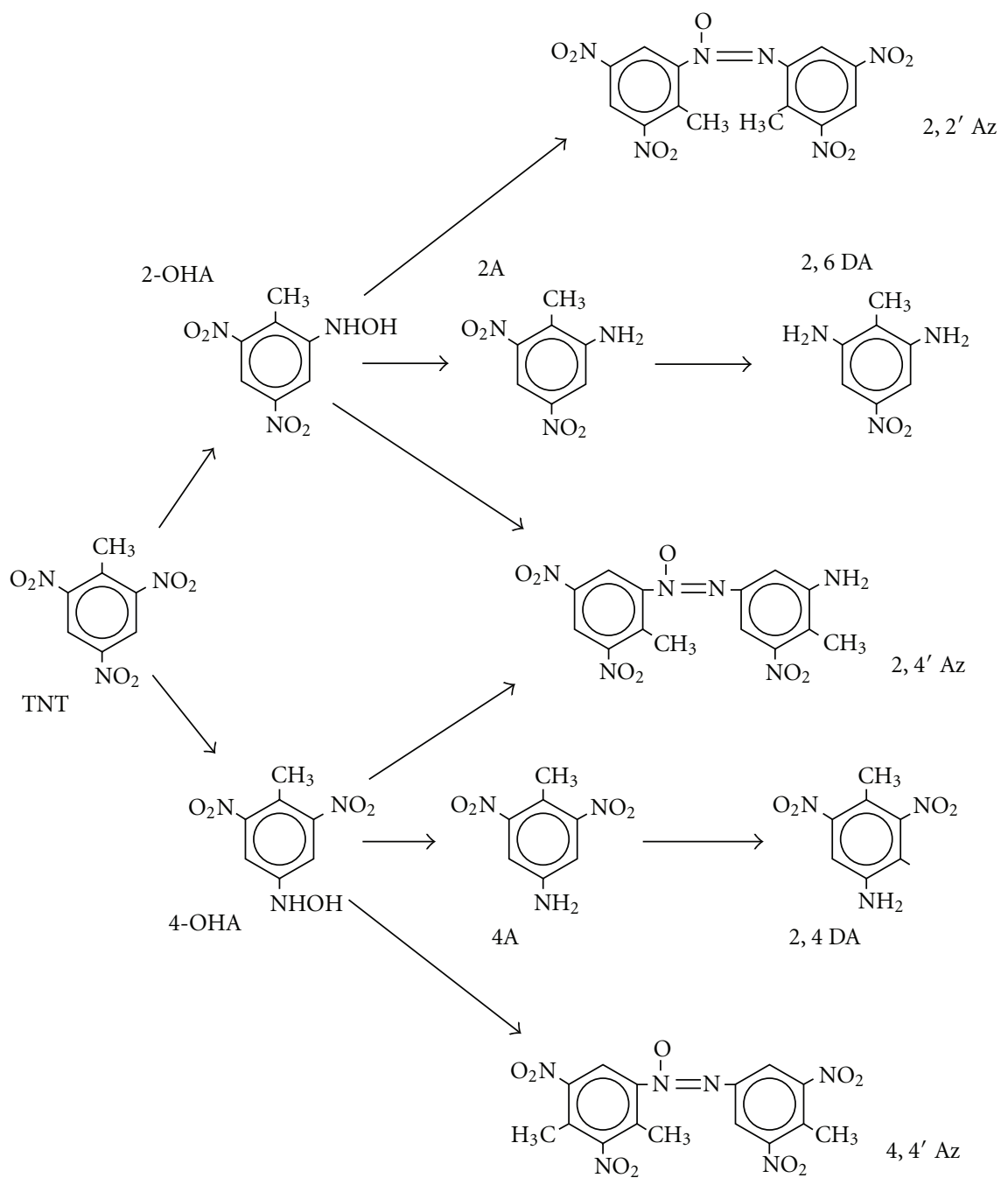

FIGURE 4: Biological transformation pathway of TNT [217]. Reproduced with kind permission from The American Society for Microbiology.

Degradation under anaerobic conditions may occur via reduction of nitro groups or direct ring cleavage. Sequential reduction of the nitro groups results in the generation of MNX, DNX, and TNX [33]. It is proposed that further transformation results in the formation of hydroxylamine derivatives; however, these products have not been isolated. Hawari et al. [43] proposed that when the first bond in the molecule is broken, the molecule is destabilized such that it undergoes spontaneous decomposition. The $\mathrm{N}-\mathrm{N}$ bond is described as the most likely target for degradation. The products may be further transformed, ultimately resulting in the production of nitramine and formaldehyde. Nitramine may be abiotically transformed to $\mathrm{N}_{2} \mathrm{O}$. The actions of acetogenic and methanogenic bacteria convert formaldehyde to $\mathrm{CO}_{2}$ [33].

Clostridium bifermentans was the first pure strain capable of anaerobic degradation of RDX to be isolated [240]. It was purified from an anaerobic consortium and removed $0.23 \mathrm{mM}$ RDX to $25 \%$ of its original concentration within $24 \mathrm{~h}$. Morganella morganii, which removed $0.33 \mathrm{mM}$ RDX under oxygen-depleted conditions within $27 \mathrm{~d}$, was the most efficient isolate from the family Enterobacteriaceae [249]. Several strains which could biotransform RDX anaerobically were isolated from horse manure, the most effective being Serratia marcescens which removed $0.23 \mathrm{mM}$ RDX over 10 days [250].

In a study by Sheremata and Hawari [251], P. Chrysosporium removed RDX $(62 \mathrm{mg} / \mathrm{L})$ from liquid medium containing glycerol as the main carbon source. Approximately $53 \%$ of the molecule was mineralized, $11 \%$ of the $\mathrm{C}$ was incorporated into fungal biomass, and $28 \%$ remained in the aqueous phase as unidentified metabolites. The major byproduct (62\%) of fungal degradation was $\mathrm{N}_{2} \mathrm{O}$.

Bacterial mineralization occurs under aerobic conditions where the RDX molecule serves as a nitrogen source (Figure 5) [252, 253]. The first reported (1983) aerobic degradation of RDX identified three pure strains of Corynebacterium capable of growing on RDX as a sole nitrogen source [254]. The most effective strain removed $0.18 \mathrm{mM}$ RDX from culture over $32 \mathrm{~h}$. A consortium of bacteria from contaminated soil was later reported to degrade $38 \%$ of $100 \mathrm{mM}$ RDX over $5 \mathrm{~d}$ [255], and a pure 


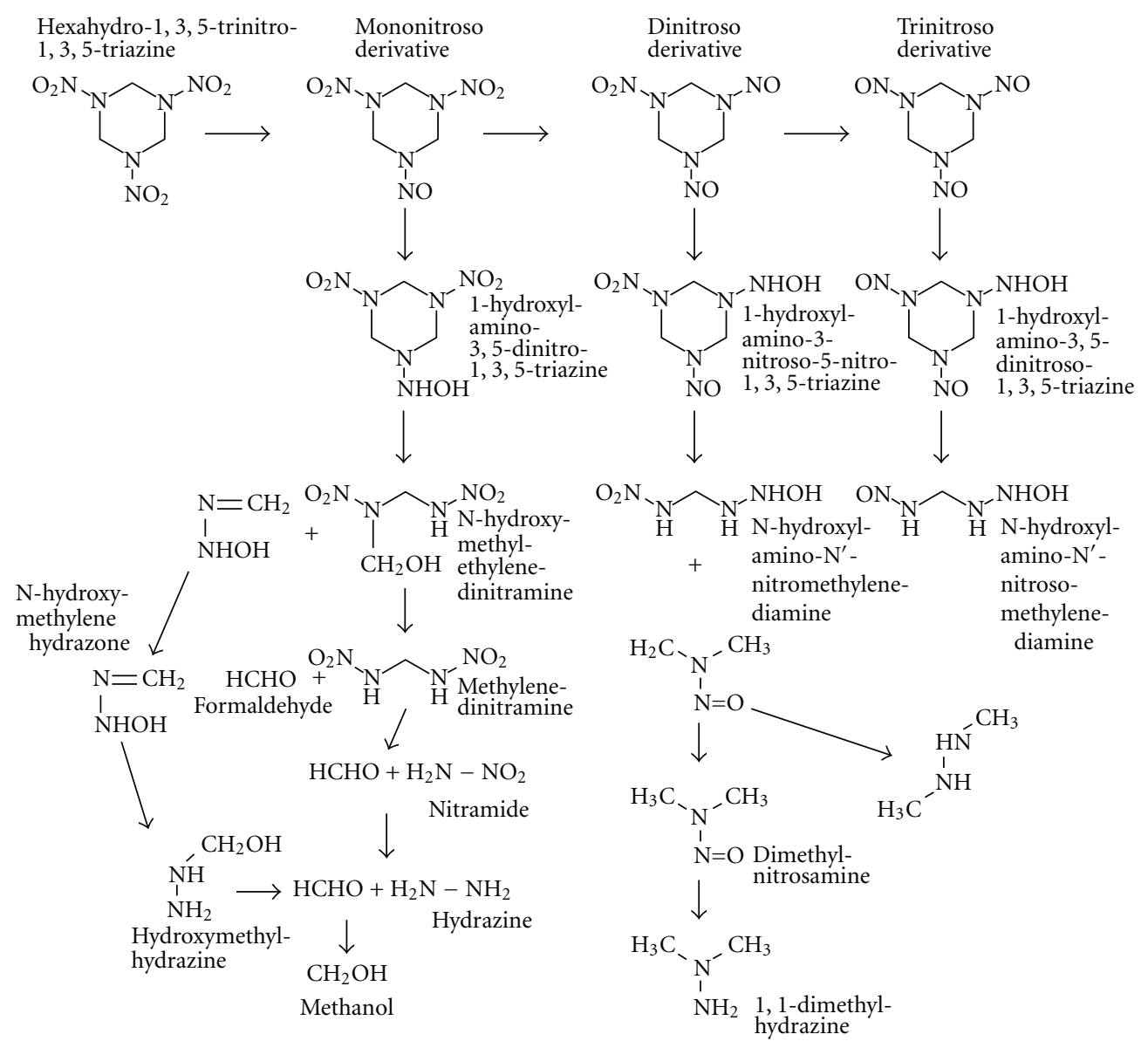

FIGURE 5: Biological transformation pathway of RDX [37].

aerobic bacterial strain, also isolated from contaminated soil, removed $0.23 \mathrm{mM}$ RDX from culture over $40 \mathrm{~h}$ [256].

4.7.3. HMX. HMX is rather recalcitrant to mineralization $[212,239]$. Bacterial degradation may occur via reduction of the nitro groups to form nitroso intermediates (Figure 6) which are subsequently transformed to $\mathrm{N}_{2} \mathrm{O}$ and formaldehyde, and eventually to $\mathrm{CO}_{2}$ [36] .

Aerobic degradation of HMX by Methylobacterium sp. strain BJ001 was reported by Van Aken et al. [257]. After 55 $\mathrm{d}$ incubation, $61 \%$ of $\mathrm{HMX}$ was mineralized to $\mathrm{CO}_{2}$. Axtell et al. [258] reported removal of HMX from contaminated soil after amending with nutrients and Pleurotus ostreatus. During $62 \mathrm{~d}$ incubation HMX was reduced from $61 \pm$ $20 \mathrm{mg} / \mathrm{kg}$ to $18 \pm 7 \mathrm{mg} / \mathrm{kg}$. Phanerochaete chrysosporium mineralized HMX under nitrogen-limiting conditions [259]. After $25 \mathrm{~d}$ incubation, 97\% of HMX was removed via reduction; 1-NO-HMX accumulated in the culture medium. The concentration of 1-NO-HMX peaked after $12 \mathrm{~d}$; a subsequent decrease in concentration corresponded to release of ${ }^{14} \mathrm{CO}_{2}$ and the accumulation of 4-nitro-2,4-diazabutanal.

HMX degradation in marine sediment from a military UXO disposal site was enhanced in the presence of glucose
[260]. After $50 \mathrm{~d}$ the HMX concentration in the aqueous phase $(1.2 \mathrm{mg} / \mathrm{L})$ was reduced by $50 \%$. The disappearance of HMX was accompanied by the formation of a mononitroso derivative. Boopathy [261] reported degradation to methanol and chloroform under sulfate-reducing, nitratereducing, fermenting, methanogenic, and mixed-electron accepting conditions using an anaerobic digester sludge enrichment culture. Rates varied from $22 \mathrm{mg} / \mathrm{L}$ on day 0 to $<0.05 \mathrm{mg} / \mathrm{L}$ on day 11 .

4.7.4. Dinitrotoluenes. Extensive studies have been conducted regarding biodegradation of dinitrotoluenes [262, 263]. Under aerobic conditions both 2,6-DNT and 2,4-DNT are susceptible to elimination of a nitro group ultimately yielding $\mathrm{NO}_{2}{ }^{-}$and catechols. In anaerobic conditions cometabolic reduction of nitro groups to nitroso-, aminonitro-, diamino-, and azoxy compounds has been observed [218, 232, 264, 265]. In bioreactor systems degradation rates of $86 \mathrm{mg} 2,4-\mathrm{DNT} / \mathrm{L} / \mathrm{h}$ have been determined $[264,266]$.

4.7.5. NG, NQ, and Perchlorates. A review of degradation of nitrate esters was provided by Williams and Bruce [267]. 


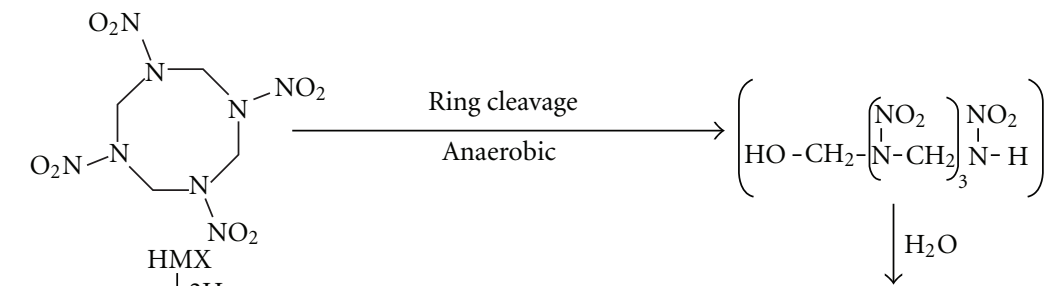<smiles>O=NN1CN([N+](=O)[O-])CN([N+](=O)[O-])CN([N+](=O)[O-])C1</smiles>

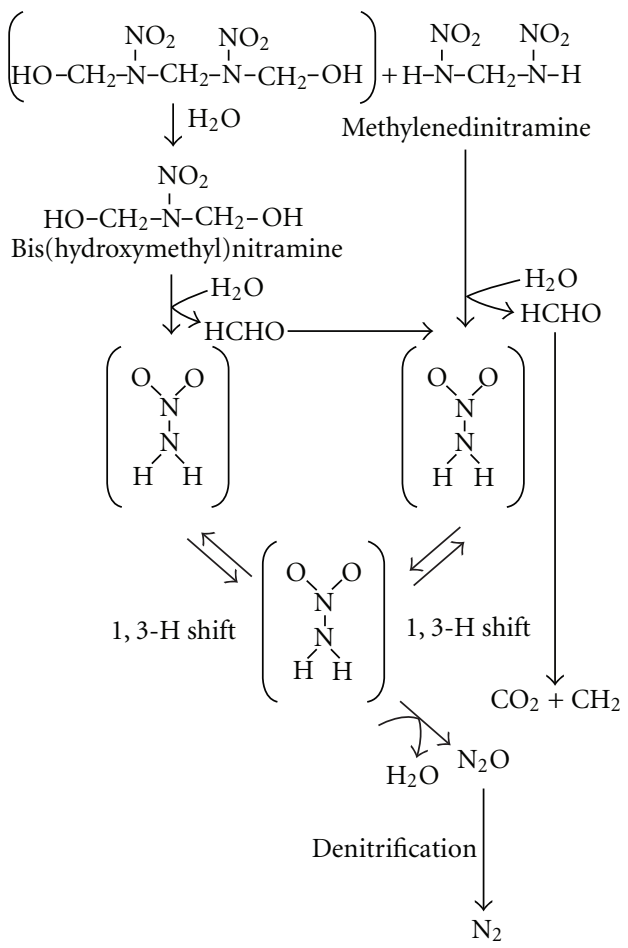

FIGURE 6: Biological transformation pathway of HMX [33]. Reproduced with kind permission from The International Union of Pure and Applied Chemistry.

Several NG-degrading microbial cultures have been identified [268-270]. Biodegradation of nitrate esters occurs through successive denitrations, each nitro group reacting more slowly than the previous one (Figure 7) [270-272]. Degradation of NG results in the production of glycerol in some cases [269, 272], which is used as a carbon source $[2,273]$. Such activity has been observed under both aerobic and anaerobic conditions, using mixed cultures or pure strains including Pseudomonas sp., Agrobacterium radiobacter and Bacillus sp. [269-272, 274, 275]. Enzymes catalyzing this reaction have been isolated from nitrate ester-degrading organisms; all have been reductases [273, 276, 277].

Both Pseudomonas putida and P. fluorescens, isolated from NG-contaminated soils, sequentially degraded NG to dinitroglycerin (DNG) $\left(\mathrm{C}_{3} \mathrm{H}_{6} \mathrm{NO}_{7}\right)$ and glycerol mononitrate $(\mathrm{GMN})\left(\mathrm{C}_{3} \mathrm{H}_{7} \mathrm{NO}_{5}\right)$ isomers [278]. Wendt et al. [270] showed that without a carbon supplement the ability of Pseudomonas to degrade NG is significantly reduced. A wastewater disposal lagoon at a former NG production plant contained Arthrobacter ureafaciens, Klebsiella oxytoca, and a Rhodococcus [279]. These bacteria were capable of degrading
NG and producing GDN and GMN. Moreover, Rhodococcus species removed the final nitro group from GMN thus achieving complete NG biodegradation.

Penicillium corylophilum Dierckx, Bacillus thuringiensis, and $B$. cereus were capable of denitrating NG to glycerol $[269,279]$. Phanerochaete chrysosporium denitrified NG in an aerobic environment without added carbon. However, this process was greatly enhanced when a carbon source was added. Christodoulates et al. [272] showed that mixed bacterial cultures in anaerobic microcosms mineralized NG more rapidly in the presence of a carbon source. Nitroglycerin mineralization was complete in $26 \mathrm{~d}$ with addition of $2000 \mathrm{mg} / \mathrm{L}$ glucose as compared with 114 days without a carbon source [280].

In a study by Brannon et al. [188], concentrations of NQ in solution phase did not change over time, which reflects the lack of susceptibility of NQ to aerobic biodegradation in activated sludge.

Degradation of perchlorate is carried out directly by soil microorganisms and also by enzymes such as perchlorate reductase and chlorite dismutase [281]. A number of 


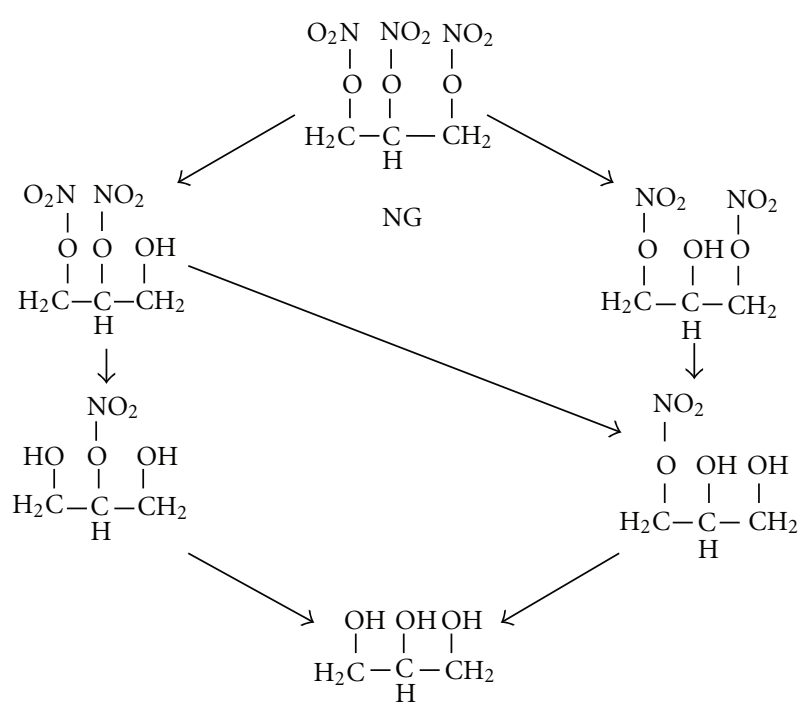

FIGURE 7: Biological transformation pathway for NG [272]. Reproduced with kind permission from Elsevier.

perchlorate-reducing bacteria have been isolated; they are all Gram-negative, facultative anaerobes [64]. Tipton et al. [101], using surface and subsurface soils and dredge tailings, demonstrated that perchlorate biodegradation requires anaerobic conditions, an adequate carbon source, and an active perchlorate-degrading microbial population. Brannon et al. [188] observed a slight decrease in solution phase perchlorate concentration in clay at $-150 \mathrm{mV}$ and $\mathrm{pH}$ 7.0.

Perchlorate degradation is generally accepted to proceed via the pathway, $\mathrm{ClO}_{4}{ }^{-} \rightarrow \mathrm{ClO}_{3}{ }^{-} \rightarrow \mathrm{ClO}_{2}^{-} \rightarrow \mathrm{Cl}^{-}+\mathrm{O}_{2}$ (Figure 8) [282]. A wide variety of organic compounds including alcohols and carboxylic acids are used as growth substrates by perchlorate-reducing bacteria although their use is strain-dependent [64]. Acetate-oxidizing chloratereducing bacteria represent a significant population from varied sources, including noncontaminated soils, hydrocarbon-contaminated soils, aquatic sediments, papermill sludges, and livestock waste lagoons [283]. Acetate has been most frequently used as a substrate for heterotrophic perchlorate reduction [284-288], although hydrogen or formate is required as an electron donor in limited cases [285]. Perchlorate reduction by Citrobacter [289] was sustained on acetate, but yeast extract improved growth.

\section{Summary and Conclusions}

Energetic materials have contaminated soils worldwide from manufacturing operations, military conflict, and military training activities. Explosives such as TNT, RDX, and HMX and propellants such as NG and perchlorates present the greatest concern to public health and the environment because they are manufactured and used in the greatest quantities. Types of residues, concentrations, and distributions differ depending on the type of range (e.g., bomb drops versus demolition) and munition used. Distribution of energetics in soil is highly variable-concentrations vary by

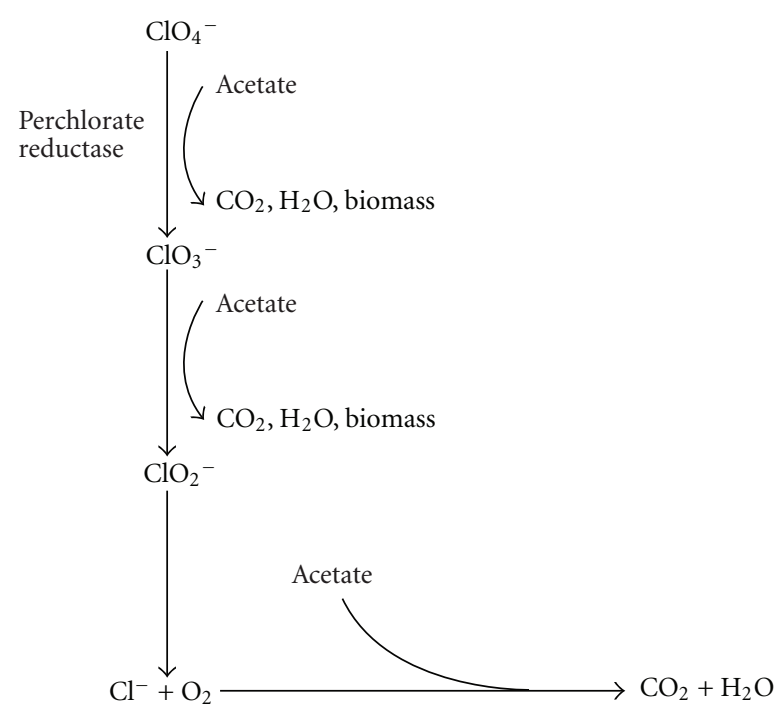

FIGURE 8: Biological transformation pathway for perchlorate (Adapted from $[64,282]$ ).

orders of magnitude across short distances on the surface, and often with only slight depth. Both low-order detonations and UXO comprise the highest concentrations of energetics contamination.

Energetic compounds undergo varying degrees of chemical and biochemical transformation, depending on the compounds involved and environmental factors. Both RDX and perchlorate appear to be common groundwater contaminants; however, several energetics, including some decomposition products (e.g., DNTs, amino-DNTs), pose health and environmental hazards.

In several countries assessment of soil contamination by explosives residues and UXOs has been highly effective, resulting in extensive cleanup; however, many nations continue to be plagued by massive dispersion of UXOs and munitions, often from conflicts decades past. There is an urgent need to identify, limit public access to, and remove such hazards to ensure public safety, promote local economic development, and protect local natural resources over the long term.

\section{References}

[1] S. Thiboutot, G. Ampleman, and A. Hewitt, "Guide for characterization of sites contaminated with energetic materials," Tech. Rep. ERDC/CRREL TR-02-1, US Army Engineer Research and Development Center, Hanover, NH, USA, 2002.

[2] T. F. Jenkins, J. C. Pennington, G. Ampleman et al., "Characterization and fate of gun and rocket propellant residues on testing and training ranges: interim report 1," Tech. Rep. ERDC TR-07-01, Strategic Environmental Research and Development Program, Vicksburg, Miss, USA, 2007.

[3] J. C. Pennington, T. F. Jenkins, G. Ampleman et al., "Distribution and fate of energetics on DOD test and training ranges: final report," ERDC TR-06-13, US Army Corps 
of Engineers Engineer Research and Development Center, Vicksburg, Miss, USA, 2006.

[4] ATSDR, "2,4,6-Trinitrotoluene (TNT) fact sheet," 1996, http://www.atsdr.cdc.gov/tfacts78.html.

[5] ATSDR, "RDX fact sheet," 1996, http://www.atsdr.cdc.gov/ tfacts78.html.

[6] P. Y. Robidoux, C. Svendsen, J. Caumartin et al., "Chronic toxicity of energetic compounds in soil determined using the earthworm (Eisenia andrei) reproduction test," Environmental Toxicology and Chemistry, vol. 19, no. 7, pp. 1764-1773, 2000.

[7] O. Drzyzga, T. Gorontzy, A. Schmidt, and K. H. Blotevogel, "Toxicity of explosives and related compounds to the luminescent bacterium Vibrio fischeri NRRL-B-11177," Archives of Environmental Contamination and Toxicology, vol. 28, no. 2, pp. 229-235, 1995.

[8] S. E. George, G. Huggins-Clark, and L. R. Brooks, "Use of a Salmonella microsuspension bioassay to detect the mutagenicity of munitions compounds at low concentrations," Mutation Research, vol. 490, no. 1, pp. 45-56, 2001.

[9] B. Lachance, P. Y. Robidoux, J. Hawari, G. Ampleman, S. Thiboutot, and G. I. Sunahara, "Cytotoxic and genotoxic effects of energetic compounds on bacterial and mammalian cells in vitro," Mutation Research, vol. 444, no. 1, pp. 25-39, 1999.

[10] E. L. Tan, C. H. Ho, W. H. Griest, and R. L. Tyndall, "Mutagenicity of trinitrotoluene and its metabolites formed during composting," Journal of Toxicology and Environmental Health, vol. 36, no. 3, pp. 165-175, 1992.

[11] W.-Z. Whong and G. S. Edwards, "Genotoxic activity of nitroaromatic explosives and related compounds in Salmonella typhimurium," Mutation Research, vol. 136, no. 3, pp. 209-215, 1984.

[12] L. J. Burdette, L. L. Cook, and R. S. Dyer, "Convulsant properties of cyclotrimethylenetrinitramine (RDX): spontaneous, audiogenic, and amygdaloid kindled seizure activity," Toxicology and Applied Pharmacology, vol. 92, no. 3, pp. 436444, 1988.

[13] W. F. von Oettingen, D. D. Donahue, H. Y. Yagonda, A. R. Monaco, and M. R. Harris, "Toxicity and potential dangers of cyclotrimethylenetrinitramine (RDX)," Journal of Industrial Hygiene and Toxicology, vol. 31, pp. 21-31, 1949.

[14] C. Smith-Simon and S. Goldhaber, "RDX - ATSDR toxicological profile," Report 205-93-0606, US Department of Health and Human Services, Atlanta, Ga, USA, 1999.

[15] A. S. Kaplan, C. F. Berghout, and A. Peczenik, "Human intoxication from RDX," Archives of Environmental Health, vol. 10, pp. 877-883, 1965.

[16] ATSDR, "HMX fact sheet," 1996, http://www.atsdr.cdc.gov/ tfacts98.html.

[17] A. Crockett, H. Craig, and T. Jenkins, "Field sampling and selecting on-site analytical methods for explosives in water," Report EPA/600/S-99/002, US Environmental Protection Agency, Washington, DC, USA, 1999.

[18] J. C. Pennington, T. F. Jenkins, G. Ampleman et al., "Distribution and fate of energetics on DOD test and training ranges: interim report 6," TR 06-12, Strategic Environmental Research and Development Program, US Army Corps of Engineers Engineer Research and Development Center, Vicksburg, Miss, USA, 2006.

[19] M. Sittig, Handbook of Toxic and Hazardous Chemicals, Noyes Publications, Park Ridge, NJ, USA, 3rd edition, 1991.
[20] W. N. Rom, Environmental and Occupational Medicine, Little, Brown and Company, Boston, Mass, USA, 2nd edition, 1992.

[21] OSHA, "Occupational safety and health guideline for nitroglycerin,” http://www.osha.gov/SLTC/healthguidelines/ nitroglycerin/recognition.html.

[22] ATSDR, “Toxic substances portal-perchlorates,” 2011, http://www.atsdr.cdc.gov/toxfaqs/.

[23] E. P. H. Best, S. L. Sprecher, S. L. Larson, H. L. Fredrickson, and D. F. Bader, "Environmental behavior of explosives in groundwater from the Milan army ammunition plant in aquatic and wetland plant treatments. Removal, mass balances and fate in groundwater of TNT and RDX," Chemosphere, vol. 38, no. 14, pp. 3383-3396, 1999.

[24] H. R. Beller and K. Tiemeyer, "Use of liquid chromatography/tandem mass spectrometry to detect distinctive indicators of in situ RDX transformation in contaminated ground water," Environmental Science and Technology, vol. 36, pp. 2060-2066, 2002.

[25] R. F. Spalding and J. W. Fulton, "Groundwater munition residues and nitrate near Grand Island, Nebraska, U.S.A.," Journal of Contaminant Hydrology, vol. 2, no. 2, pp. 139-153, 1988.

[26] K. Spiegel, J. V. Headley, K. M. Peru, N. Haidar, and N. P. Gurprasard, "Residues of explosives in groundwater leached from soils at a military site in Eastern Germany," Communications in Soil Science and Plant Analysis, vol. 36, no. 1-3, pp. 133-153, 2005.

[27] R. Martel, M. Mailloux, U. Gabriel, R. Lefebvre, S. Thiboutot, and G. Ampleman, "Behavior of energetic materials in ground water at an anti-tank range," Journal of Environmental Quality, vol. 38, no. 1, pp. 75-92, 2009.

[28] R. Martel, T. J. Robertson, D. M. Quan et al., “2,4,6Trinitrotoluene in soil and groundwater under a waste lagoon at the former Explosives Factory Maribyrnong (EFM), Victoria, Australia," Environmental Geology, vol. 53, no. 6, pp. 1249-1259, 2008.

[29] S. Hains, R. Martel, R. Lefebvre et al., in Proceedings of the 54th Canadian Geotechnical Conference: an Earth Odyssey, pp. 16-19, Calgary, Canada, September 2001.

[30] J. Clausen, J. Robb, D. Curry, M. Wojtas, and B. Gallagher, "Analytes of interest at military ranges," in Proceedings of the National Defense Industry Association Annual Meeting, Arlington, Va, USA, April 2003.

[31] D. Armstrong, "US presence on foreign soil is tainted," Boston Globe, November 15, 1999.

[32] D. Armstrong, "More costly cleanup on horizon," Boston Globe, November 14, 1999.

[33] D. Kalderis, A. L. Juhasz, R. Boopathy, and S. Comfort, "Soils contaminated with explosives: environmental fate and evaluation of state-of-the-art remediation processes (IUPAC technical report)," Pure and Applied Chemistry, vol. 83, no. 7, pp. 1407-1484, 2011.

[34] J. Eriksson, S. Frankki, A. Shchukarev, and U. Skyllberg, "Binding of 2,4,6-trinitrotoluene, aniline, and nitrobenzene to dissolved and particulate soil organic matter," Environmental Science and Technology, vol. 38, no. 11, pp. 3074-3080, 2004.

[35] J. Pichtel, Terrorism and WMDs: Awareness and Response, CRC Press, Boca Raton, Fla, USA, 2011.

[36] A. L. Juhasz and R. Naidu, "Explosives: fate, dynamics, and ecological impact in terrestrial and marine environments," Reviews of Environmental Contamination and Toxicology, vol. 191, pp. 163-215, 2007. 
[37] J. M. Brannon and J. C. Pennington, "Environmental fate and transport process descriptors for explosives," ERDC/EL TR-02-10, U.S Army Engineer Research and Development Center, Vicksburg, Miss, USA, 2002.

[38] D. C. Leggett, T. F. Jenkins, and R. P. Murrmann, "Composition of vapors evolved from military TNT as influenced by temperature, solid composition, age and source," Special Report 77-16, Cold Regions Research and Engineering Laboratory, Hanover, NH, USA, 1977.

[39] T. F. Jenkins, G. Ampleman, S. Thiboutot et al., "Characterization and fate of gun and rocket propellant residues on testing and training ranges: final report," TR 08-01, Strategic Environmental Research and Development Program, Cold Regions Research and Engineering Laboratory, US Army Engineer Research and Development Center, Hanover, NH, USA, 2008.

[40] M. E. Walsh, T. F. Jenkins, P. S. Schnitker, J. W. Elwell, and M. H. Stutz, "Evaluation of SW846 Method 8330 for characterization of sites contaminated with residues of high explosives," CRREL Report 93-5, US Cold Regions Research and Engineering Laboratory, Hanover, NH, USA, 1993.

[41] US EPA, Contaminated Site Clean-Up Information, Technology Innovation and Field Services Division, US Environmental Protection Agency, Washington, DC, USA, 2010.

[42] Global Security, "Explosives-nitroaromatics," 2008, http:// www.globalsecurity.org/military/systems/munitions/explosives-nitroaromatics.htm.

[43] J. Hawari, "Biodegradation of RDX and HMX: from basic research to field application," in Biodegradation of Nitroaromatic Compounds and Explosives, pp. 277-310, Plenum Press, New York, NY, USA, 2000.

[44] H. Ullah, A. A. Shah, F. Hasan, and A. Hameed, "Biodegradation of trinitrotoluene by immobilized Bacillus Sp. Yrel," Pakistan Journal of Botany, vol. 42, no. 5, pp. 3357-3367, 2010.

[45] J. Yinon, Toxicity and Metabolism of Explosives, CRC Press, Boca Raton, Fla, USA, 1990.

[46] J. H. Sullivan, H. D. Puttman, M. A. Keirn, B. C. Pruitt, J. C. Nichols, and J. T. McClave, A Summary and Evaluation of Aquatic Environmental Data in Relation to Establishing Water Quality Criteria for Munitions Unique Compounds: Part 2. Nitroglycerin, Water and Air Research, US Army Medical Research and Development Command, Gainesville, Fla, USA, 1979.

[47] R. Boopathy, "Enhanced biodegradation of cyclotetramethylenetetranitramine (HMX) under mixed electron-acceptor condition," Bioresource Technology, vol. 76, pp. 241-244, 2001.

[48] F. Monteil-Rivera, L. Paquet, S. Deschamps, V. K. Balakrishnan, C. Beaulieu, and J. Hawari, "Physico-chemical measurements of CL-20 for environmental applications: comparison with RDX and HMX," Journal of Chromatography, vol. 1025, pp. 125-132, 2004.

[49] M. R. Walsh, M. E. Walsh, A. D. Hewitt, and C. M. Collins, "Field-expedient disposal of excess artillery propellants," in Proceedings of the SERDP \& ESTCP's Partners in Environmental Technology Technical Symposium \& Workshop, Washingto, DC, USA, December 2008.

[50] National Forensic Science Technology Center, "Propellants," Firearm Examiner Training, 2011, http://projects.nfstc.org/ firearms/module05/fir_m05_t04_01.htm.

[51] D. H. Rosenblatt, E. P. Burrows, W. R. Mitchell, and D. L. Palmer, "Organic explosives and related compounds," in The
Handbook of Environmental Chemistry, O. Hutziner, Ed., vol. 3, pp. 195-234, Springer, Berlin, Germany, 1989.

[52] D. C. Leggett, T. F. Jenkins, and R. P. Murrmann, "Composition of vapors evolved from military TNT as influenced by temperature, solid composition, age and source," Special Report 77-16, Cold Regions Research and Engineering Laboratory, Hanover, NH, USA, 1977.

[53] Fisher Scientific, "Material Safety Data Sheet, Nitroguanidine, 99\%, Moistened With ca 25\% Water," 2008, https:// fscimage.fishersci.com/msds/07334.htm.

[54] G. Bordeleau, R. Martel, G. Ampleman, and S. Thiboutot, "Environmental impacts of training activities at an air weapons range," Journal of Environmental Quality, vol. 37, pp. 308-317, 2008.

[55] ATSDR, Toxicological Profile for 2,4-Dinitrotoluene and 2,6Dinitrotoluene, US Public Health Service, US Department of Health and Human Services, Atlanta, Ga, USA, 1989.

[56] Code of Federal Regulations (CFR), Appendix A to Part 423-126 Priority Pollutants, Title 40-Protection of Environment, http://ecfr.gpoaccess.gov/cgi/t/text/text-idx?c $=$ ecfr $\&$ tpl $=\% 2$ Findex.tpl.

[57] K. A. Thorn, J. C. Pennington, K. R. Kennedy, L. G. Cox, C. A. Hayes, and B. E. Porter, "N-15 NMR study of the immobilization of 2,4- and 2,6-dinitrotoluene in aerobic compost," Environmental Science and Technology, vol. 42, pp. 25422550, 2008.

[58] M. Uchimiya, "Reductive transformation of 2,4-dinitrotoluene: roles of iron and natural organic matter," Aquatic Geochemistry, vol. 16, pp. 547-562, 2010.

[59] E. T. Urbansky, "Perchlorate chemistry: implications for analysis and remediation," Bioremediation, vol. 2, pp. 81-95, 1998.

[60] R. Q. Gullick, M. W. Lechvallier, and T. A. S. Barhorst, "Occurrence of perchlorate in drinking water sources," Journal of the American Water Works Association, vol. 39, pp. 6677, 2001.

[61] B. E. Logan, "Assessing the outlook for perchlorate remediation," Environmental Science and Technology, vol. 35, pp. 482A-487A, 2001.

[62] W. E. Motzer, "Perchlorate: problems, detection, and solutions," Environmental Forensics, vol. 2, pp. 301-311, 2001.

[63] C. W. Trumpolt, M. Crain, C. D. Cullison, S. J. P. Flanagan, L. Siegel, and S. Lathrop, "Perchlorate: sources, uses, and occurrences in the environment," Remediation Journal, vol. 16, no. 1, pp. 65-89, 2005.

[64] J. Xu, Y. Song, B. Min, L. Steinberg, and B. E. Logan, "Microbial degradation of perchlorate: principles and applications," Environmental Engineering Science, vol. 20, no. 5, pp. 405422, 2003.

[65] S. Thiboutot, G. Ampleman, A. Marois et al., "Environmental conditions of surface soils, CFB gagetown training area: delineation of the presence of munitions-related residues (phase III, final report)," Tech. Rep. DREV-TR-2004-205, Defence Research and Development Canada-Valcartier, Quebec, Canada, 2004, http://cradpdf.drdc.gc.ca/PDFS/ unc57/p522641.pdf.

[66] S. Thiboutot, G. Ampleman, A. Marois et al., "Environmental condition of surface soils and biomass prevailing in the training area at CFB Gagetown, New Brunswick," DRDC Valcartier TR 2003-152, Defence Research and Development Canada-Valcartier, Quebec, Canada, 2004.

[67] S. Thiboutot, G. Ampleman, A. Gagnon et al., "Characterization of antitank firing ranges at CFB valcartier, WATC 
Wainwright and CFAD Dundurn," Quebec Report DREVR9809, Defence Research Establishment Valcartier, Quebec, Canada, 1998.

[68] M. E. Walsh, C. H. Racine, T. F. Jenkins, A. Gelvin, and T. A. Ranney, "Sampling for explosives residues at Fort Greely, Alaska," ERDC/CRREL TR-01-15, US Army Cold Regions Research and Engineering Laboratory, Hanover, NH, USA, 2001.

[69] Government Accountability Office (GAO), "DOD operational ranges-more reliable cleanup cost estimates and a proactive approach to identifying contamination are needed," GAO-04-601, 2004, http://www.gao.gov/htext/ d04601.html.

[70] ATSDR, "Redstone Army Garrison/Marshall Space Flight Center Huntsville, Madison County, Alabama," Public Health Assessments and Health Consultations, 2005 http:// www.atsdr.cdc.gov/HAC/pha/RedstoneArmy/RedstoneArmyPHA071205.pdf.

[71] T. F. Jenkins, M. E. Walsh, P. G. Thorne et al., "Site characterization at the inland firing range impact area at Fort Ord," Special Report 98-9, US Army Cold Regions Research and Engineering Laboratory, 1998.

[72] A. D. Hewitt, T. F. Jenkins, M. E. Walsh, M. R. Walsh, and S. Taylor, "RDX and TNT residues from live-fire and blow-inplace detonations," Chemosphere, vol. 61, pp. 888-894, 2005.

[73] A. D. Hewitt, T. F. Jenkins, T. A. Ranney, D. Lambert, and N. Perron, "Characterization of energetic residues at firing ranges: schofield barracks and training area," Distribution and Fate of Energetics on DoD Test and Training Ranges, Interim Report 4 ERDC TR-04-4, US Army Engineer Research and Development Center, Vicksburg, Miss, USA, 2004.

[74] J. C. Pennington, T. F. Jenkins, S. Thiboutot et al., "Distribution and fate of energetics on DoD test and training ranges: interim report 5," TR 05-2, Strategic Environmental Research and Development Program, US Army Corps of Engineers Engineer Research and Development Center, Vicksburg, Miss, USA, 2005.

[75] ATSDR, Weldon Spring Ordnance Works, Weldon Spring, St. Charles County, Missouri, Public Health Assessments and Health Consultations, 2010, http://www.atsdr.cdc.gov/ $\mathrm{HAC} / \mathrm{pha} / \mathrm{pha}$.asp?docid=871\&pg=2.

[76] Environmental Science \& Engineering, Draft Final Remedial Investigation/Baseline Risk Assessment Explosives-Munitions Manufacturing Areas Operable Unit, vol. I-V, Crab Orchard National Wildlife Refuge, Louis, Mo, USA, 1994.

[77] USACHPPM, "Training range site characterization and risk screening, regional range study, Dona Ana Range, Fort Bliss, Texas, May 2002," Geohydrologic Study 38-EH-6807-02, US Army Center for Health Promotion and Preventive Medicine, Aberdeen Proving Ground, MD, USA, 2004.

[78] J. C. Pennington, T. F. Jenkins, G. Ampleman et al., "Distribution and fate of energetics on dod test and training ranges: interim report 2," ERDC TR-02-8, US Army Engineer Research and Development Center, Vicksburg, Miss, USA, 2002.

[79] US Environmental Protection Agency, "EPA superfund record of decision: Umatilla Army Depot (Lagoons), Hermiston, OR," EPA/ROD/R10-94/094, 1994.

[80] ATSDR, US Army Umatilla Depot Activity. Hermiston, Umatilla County, Oregon, Public Health Assessments and Health Consultations, 2009, http://www.atsdr.cdc.gov/HAC/ pha/PHA.asp? docid=290\&pg=1.
[81] ATSDR, Tooele Army Depot (North Area), Tooele, Tooele County, Utah, Public Health Assessments and Health Consultations, 2010, http://www.atsdr.cdc.gov/HAC/pha/pha .asp?docid=108\&pg=1.

[82] ATSDR, Former Nansemond Ordnance Depot, Suffolk, Virginia, Public Health Assessments and Health Consultations, 2009, http://www.atsdr.cdc.gov/HAC/pha/pha.asp ?docid=497\&pg=3.

[83] T. F. Jenkins, J. C. Pennington, T. A. Ranney et al., "Characterization of explosives contamination at military firing ranges," ERDC TR-01-05, US Army Engineer Research and Development Center, Hanover, NH, USA, 2001.

[84] US Environmental Protection Agency, "EPA Superfund Record of Decision: Bangor Naval Submarine Base, Silverdale, WA," EPA/ROD/R10-94/107, 1994, http://www.epa .gov/superfund/sites/rods/fulltext/r1094107.pdf.

[85] ATSDR, Former Dupont Cladding Site at Cabin Lake (Aka Dupont Barksdale Explosives Plant), WI, Public Health Assessments and Health Consultations, 2009, http://www .atsdr.cdc.gov/HAC/pha/pha.asp?docid=750\&pg=1.

[86] J. M. Brannon and T. E. Myers, "Review of fate and transport processes of explosives," Tech. Rep. IRRP-97-2, U.S Army Engineer Waterways Experiment Station, Vicksburg, Miss, USA, 1997.

[87] US EPA, NPL Site Narrative for Pantex Plant (USDOE), PANTEX PLANT (USDOE) Pantex Village, Texas, 2011, http://www.epa.gov/superfund/sites/npl/nar1314.htm.

[88] US EPA, Joliet Army Ammunition Plant, Region 5 Superfund, 2007, http://www.epa.gov/R5Super/fed_fac/npl_sites/ ff_npl_jaap_lap.html.

[89] B. Clark and R. Boopathy, "Evaluation of bioremediation methods for the treatment of soil contaminated with explosives in Louisiana Army Ammunition Plant, Minden, Louisiana," Journal of Hazardous Materials, vol. 143, pp. 643648, 2007.

[90] R. H. Gray and D. A. McGrath, "Environmental monitoring at DOE's pantex plant in Amarillo, Texas," Federal Facilities Environmental Journal, vol. 6, no. 1, pp. 79-88, 1995.

[91] M. E. Walsh, T. F. Jenkins, P. S. Schnitker, J. W. Elwell, and M. H. Stutz, "Evaluation of SW846 method 8330 for characterization of sites contaminated with residues of high explosives," CRREL Report 93-5, US Cold Regions Research and Engineering Laboratory, Hanover, NH, USA, 1993.

[92] M. E. Walsh, A. D. Hewitt, M. R. Walsh et al., "Range characterization studies at Donnelly Training Area, Alaska: 2001 and 2002," Report ERDC/CRREL TR-04-3, US Army Cold Regions Research and Engineering Laboratory, Hanover, $\mathrm{NH}$, USA, 2004.

[93] D. L. Pugh, "Milan Army Ammunition Plant contamination survey," USATHAMA Report DRXTH-FR-8213, US Army Toxic and Hazardous Materials Agency, Aberdeen, MD, USA, 1982.

[94] Pantex, http://www.pantex.com/.

[95] B. D. Newman, D. D. Hickmott, and P. Gram, "Flow and high explosives transport in a semiarid mesa in New Mexico, USA," Vadose Zone Journal, vol. 6, pp. 774-785, 2007.

[96] Los Alamos National Laboratory, "RFI report for potential release site 16-021(c)," LA-UR-98-4101, Los Alamos National Laboratory, Los Alamos, NM, USA, 1998.

[97] ATSDR, Savanna Army Depot Activity, Savanna, Illinois, Public Health Assessments and Health Consultations, 2009, http://www.atsdr.cdc.gov/HAC/pha/pha.asp?docid=601\&pg =1\#background. 
[98] A. Eisentraeger, G. Reifferscheid, F. Dardenne, R. Blust, and A. Schofer, "Hazard characterization and identification of a former ammunition site using microarrays, bioassays, and chemical analysis," Environmental and Toxicological Chemistry, vol. 26, pp. 634-646, 2007.

[99] US EPA, “Region 9 perchlorate update," 1999, http://www .epa.gov/safewater/ccl/perchlor/r9699fac.pdf.

[100] E. T. Urbansky, M. L. Magnuson, C. A. Kelty, and S. K. Brown, "Perchlorate uptake by salt cedar (Tamarix ramosissima) in the Las Vegas Wash riparian ecosystem," Science of the Total Environment, vol. 256, pp. 227-232, 2000.

[101] D. K. Tipton, D. E. Rolston, K. M. Scow et al., "Transport and biodegradation of perchlorate in soils," Journal of Environmental Quality, vol. 32, pp. 40-46, 2003.

[102] US AEC, "Unexploded ordnance (UXO)," 2011, http://aec .army.mil/usaec/technology/uxo00.html.

[103] Landmine and Cluster Munition Monitor, "Vietnam," 2003, http://www.the-monitor.org/index.php/publications/ display?url=lm/2003/vietnam.html.

[104] BOMICO, "Tinh hinh o nhiem bom-min-vat no con sot lai sau chien tranh," (Situation on the Effects of Landmines, Bombs and Explosives Remaining after the War), draft paper provided by VVAF, p. 7, as cited in: Landmine and Cluster Munition Monitor, "Vietnam," 2003, http://www .themonitor.org/index.php/publications/display?url=lm/2003/ vietnam.html.

[105] D. Holdridge, "Viet Nam, US organisations to co-operate on mine survey," Vietnam News Service, 29 January 2003.

[106] Interview with Nguyen Quang Vinh, Director, and Amb. Nguyen Quy Binh, Vice-Director of the Boundaries Committee, Ministry of Foreign Affairs, Hanoi, as cited in: Landmine and Cluster Munition Monitor, "Vietnam," 2003, http://www.the-monitor.org/index.php/publications/display ?url=lm/2003/vietnam.html.

[107] T. F. Jenkins, M. E. Walsh, P. H. Miyares et al., Analysis of Explosives-Related Chemical Signatures in Soil Samples Collected Near Buried Land Mines, Engineer Research and Development Center, Hanover, NH, USA, 2000.

[108] Lao National Unexploded Ordnance Programme, "The Unexploded Ordnance (UXO) Problem," 2008, http://www .uxolao.org/uxo\%20problem.html.

[109] C. Bendinelli, "Effects of land mines and unexploded ordnance on the pediatric population and comparison with adults in rural Cambodia," World Journal of Surgery, vol. 33, no. 5, pp. 1070-1074, 2009.

[110] Landmine and Cluster Munition Monitor, Cambodia, 2009 http://www.the-monitor.org/index.php/publications/display ?act=submit\&pqs_year=2002\&pqs_type=lm\&pqs_report $=$ cambodia\&pqs_section=\%23Heading3334\#Heading3334.

[111] Australian Department of Defense, "UXO contamination sites—by state," 2010, http://www.defence.gov.au/uxo/drn _reports/uxo_by_state.asp.

[112] UNICEF, "Landmines and UXO in Somaliland, Puntland and Central \& Southern Somalia: a feasibility study," 2000, http://www.unicef.org/evaldatabase/files/SOM_00-003.pdf.

[113] H. Hafidh, "U.N. wants Iraq to issue more visas for its staff," Tech. Rep., Reuters, Baghdad, Iraq, 2002.

[114] New York Times, "Israeli bomblets plague Lebanon," 2006, http://www.nytimes.com/2006/10/06/world/middleeast/ 06cluster.html? pagewanted=1\&_r=1\&ref=todayspaper.

[115] A. Shadid, "In Lebanon, a war's lethal harvest," Washington Post Foreign Service, September 26, 2006, http://www .washington post.com/wp-dyn/content/article/2006/09/25/ AR2006092501500.html.
[116] Landmine and Cluster Munition Monitor, "Palestine," 2009, http://www.the-monitor.org/index.php/publications/display ?url=lm/2003/palestine.html.

[117] N. Prevost and UNICEF, "Unexploded Ordnance and Mine Action in the Occupied Palestinian Territory," Landmine and Cluster Munition Monitor, 2003, http://www.the-monitor .org/index.php/publications/display?url=lm/2003/palestine .html.

[118] Landmine and Cluster Munition Monitor, “Armenia," 2002, http://www.the-monitor.org/index.php/publications/display ?act=submit\&pqs_year=2002\&pqs_type=lm\&pqs_report=armenia\&pqs_section=\%23Heading14227\#Heading14227.

[119] Landmine and Cluster Munition Monitor, "Chechnya," 2009, http://www.the-monitor.org/index.php/publications/display ?url=lm/2003/chechnya.html.

[120] Interfax, Unexploded Federal Ammunition Makes Up Most of Landmines Used by Chechen Guerillas, Interfax, Moscow, Russia, 2003.

[121] "Unexploded federal ammunition makes up most of landmines used by Chechen guerrillas," Izvestia Interfax-AVN (Moscow), 20 May, 2003, Interview with Major Yevgeny Pasynok, Chief of Engineering Service, Grozny Military Commandant's Office.

[122] U. Khanbiev, Minister for Health of the Chechen Republic, citation translated from Russian by Landmine Monitor, 2002, http://www.chechenpress.com.

[123] O. Petrovsky, Hellish Surprises, UTRORU Information Agency, 2002.

[124] J. A. MacDonald, M. J. Small, and M. G. Morgan, "Quantifying the risks of unexploded ordnance at closed military bases," Environmental Science and Technology, vol. 43, no. 2, pp. 259-265, 2009.

[125] Defense Science Board, Report of the Defense Science Board Task Force on Unexploded Ordnance, Office of the Under Secretary of Defense for Acquisition, Technology, and Logistics, Washington, DC, USA, 2003.

[126] G. Ampleman, S. Thiboutot, S. Désilets, A. Gagnon, and A. Marois, "Evaluation of the soils contamination by explosives at CFB Chilliwack and CFAD Rocky Point," DREV Report TR-2000-103, Quebec, Canada, 2000.

[127] G. Ampleman, D. Faucher, S. Thiboutot, J. Hawari, and F. Monteil-Rivera, "Evaluation of underwater contamination by explosives and metals at Point Amour, Labrador and in the Halifax Harbour Area," DRDC Valcartier TR 2004-125, Defence Research and Development, Canada, 2004.

[128] T. F. Jenkins, A. D. Hewitt, C. L. Grant et al., "Identity and distribution of residues of energetic compounds at army livefire training ranges," Chemosphere, vol. 63, no. 8, pp. 12801290, 2006.

[129] M. E. Walsh, C. M. Collins, R. N. Bailey, and C. L. Grant, "Composite sampling of sediments contaminated with white phosphorus," Special Report 97-30, US Army Cold Regions Research and Engineering Laboratory, Hanover, NH, USA, 1997.

[130] T. F. Jenkins, C. L. Grant, M. E. Walsh et al., "Coping with spatial heterogeneity effects on sampling and analysis at an HMX-contaminated antitank firing range," Field Analytical Chemistry and Technology, vol. 3, no. 1, pp. 19-28, 1999.

[131] T. F. Jenkins, T. A. Ranney, A. D. Hewitt, M. E. Walsh, and K. L. Bjella, "Representative sampling for energetic compounds at an anti-tank firing range," ERDC/CRREL TR-04-7, US Army Engineer Research and Development Center, Hanover, NH, USA, 2004. 
[132] T. F. Jenkins, A. D. Hewitt, M. E. Walsh, C. L. Grant, and C. A. Ramsey, "Comment on data representativeness for risk assessment by Rosemary Mattuck et al.," Journal of Environmental Forensics, vol. 6, no. 4, pp. 321-323, 2005.

[133] A. D. Hewitt, T. F. Jenkins, T. A. Ranney et al., "Estimates for explosives residues from the detonation of army munitions," ERDC/ CRREL TR-03-16, US Army Engineer Research and Development Center, Hanover, NH, USA, 2003.

[134] AMEC, "Draft central impact area soil report technical team memorandum 01-13 Camp Edwards impact area groundwater quality study, Camp Edwards, Massachusetts Military Reservation, Cape Cod, MA," MMR-3915, AMEC Earth and Environmental, Westford, Mass, USA, 2001.

[135] M.R. Walsh, S. Taylor, M. E. Walsh et al., "Residues from live fire detonations of 155-mm howitzer rounds," ERDC/CRREL TR-05-14, US Army Engineer Research and Development Center, Hanover, NH, USA, 2005.

[136] S. Taylor, A. Hewitt, J. Lever et al., "TNT particle size distributions from detonated 155-mm howitzer rounds," Chemosphere, vol. 55, no. 3, pp. 357-367, 2004.

[137] J. Lewis, R. Martel, L. Trépanier, G. Ampleman, and S. Thiboutot, "Quantifying the transport of energetic materials in unsaturated sediments from cracked unexploded ordnance," Journal of Environmental Quality, vol. 38, no. 6, pp. 22292236, 2009.

[138] J. Clausen, J. Robb, D. Curry, and N. Korte, "A case study of contaminants on military ranges: Camp Edwards, Massachusetts, USA," Environmental Pollution, vol. 129, no. 1, pp. 13-21, 2004.

[139] J. L. Clausen, “Range assessment lessons learned," Federal Facilities Environment Journal, vol. 16, pp. 49-62, 2005.

[140] W. F. Fitzpatrick, The Lessons of Massachusetts Military Reservation, Massachusetts Army National Guard, AEPI-IFP1001B Army Environmental Policy Institute, Atlanta, Ga, USA, 2001.

[141] US EPA, "Administrative order for: Massachusetts Military Reservation training range and impact area," EPA Docket RCRA 1-2001-0014, Washington, DC, USA, 2001.

[142] R. Boopathy, J. Manning, and C. F. Kulpa, "Optimization of environmental factors for the biological treatment of trinitrotoluene-contaminated soil," Archives of Environmental Contamination and Toxicology, vol. 32, no. 1, pp. 94-98, 1997.

[143] USACHPPM, Draft site inspection No. 38-26-1339-95, Site CS-19, Massachusetts Military Reservation, Cape Cod, Massachusetts, US Center for Health Promotion and Preventive Medicine, Aberdeen Proving Ground, Md, USA, 1994.

[144] T. F. Jenkins, M. E. Walsh, P. G. Thorne et al., "Assessment of sampling error associated with collection and analysis of soil samples at a firing range contaminated with HMX," CRREL Report 97-22, US Army Cold Regions Research and Engineering Laboratory, Hanover, NH, USA, 1997.

[145] S. Brochu, E. Diaz, S. Thiboutot et al., "Assessment of 100 years of military training in Canada: the case of Canadian Force Base Petawawa," TR-2008-118, Defense Research Development Canada (DRDC-Valcartier), Quebec, Canada, 2008.

[146] C. H. Racine, M. E. Walsh, C. M. Collins, D. J. Calkins, B. D. Roebuck, and L. Reitsma, "Waterfowl mortality in Eagle River Flats, Alaska: the role of munition residues," CRREL Report 92-5, US Army Cold Regions Research and Engineering Laboratory, Hanover, NH, USA, 1992.

[147] L. F. Phillips and C. A. Bouwkamp, "Effects of active firing range activities on environmental media, Aberdeen Proving
Ground-Aberdeen Area, Maryland, 31 January-30 December 1993," Wastewater Management Study 32-24-HP16-94, US Army Environmental Hygiene Agency, Aberdeen Proving Ground, Md, USA, 1994.

[148] A. D. Hewitt and S. R. Bigl, "Elution of energetic compounds from propellant and composition B residues," ERDC/CRREL TR-05-13, Cold Regions Research and Engineering Laboratory, US Army Engineer Research and Development Center, Hanover, NH, USA, 2005, http://libweb.erdc.usace.army .mil/Archimages/2705.pdf.

[149] G. Bordeleau, Etude hydrogeologique de la Base Aerienne de Cold Lake, Alberta et determination de l'origine du nitrate dans l'eau souterraine, M.S. thesis, INRSEte, Quebec, Canada, 2007.

[150] D. M. Townsend and T. E. Myers, "Recent developments in formulating model descriptors for subsurface transformation and sorption of TNT, RDX, and HMX," Tech. Rep. IRRP96-1, US Army Engineer Waterways Experiment Station, Vicksburg, Miss, USA, 1996.

[151] J. Wilkinson and D. Watt, Review of Demilitarization and Disposal Techniques for Munitions and Related Materials, Munitions Safety Information Analysis Centre (MSIAC), NATO Headquarters, Brussels, Belgium.

[152] T. A. Douglas, M. E. Walsh, C. J. McGrath, C. A. Weiss, A. M. Jaramillo, and T. P. Trainor, "Desorption of nitramine and nitroaromatic explosive residues from soils detonated under controlled conditions," Environmental Toxicology and Chemistry, vol. 30, no. 2, pp. 345-353, 2010.

[153] S. Taylor, J. H. Lever, J. Fadden, N. Perron, and B. Packer, "Simulated rainfall-driven dissolution of TNT, Tritonal, Comp B and Octol particles," Chemosphere, vol. 75, no. 8, pp. 1074-1081, 2009.

[154] K. S. Ro, A. Venugopal, D. D. Adrian et al., "Solubility of 2,4,6-trinitrotoluene (TNT) in water," Journal of Chemical and Engineering Data, vol. 41, no. 4, pp. 758-761, 1996.

[155] J. M. Brannon, D. D. Adrian, J. C. Pennington, T. E. Myers, and C. A. Hayes, "Slow release of PCB, TNT, and RDX from soils and sediments," Tech. Rep. EL-92-38, US Army Corps of Engineers, Waterways Experiment Station, Vicksburg, Miss, USA, 1992.

[156] K. Verschueren, Handbook of Environmental Data on Organic Chemicals, D. Van Nostrand Reinhold Company, New York, NY, USA, 2nd edition, 1983.

[157] R. J. Spanggord, R. W. Mabey, T. W. Chou et al., "Environmental fate studies of HMX, phase II, detailed studies, final report," SRI International, Menlo Park, Calif, USA, 1983.

[158] K. M. Dontsova, J. C. Pennington, C. Hayes, J. Šimunek, and C. W. Williford, "Dissolution and transport of 2,4-DNT and 2,6-DNT from M1 propellant in soil," Chemosphere, vol. 77, no. 4, pp. 597-603, 2009.

[159] J. M. Phelan, J. V. Romero, J. L. Barnett, and D. R. Parker, "Solubility and dissolution kinetics of composition B explosive in water," SAND Report SAND2002-2420, Sandia National Laboratories, Albuquerque, NM, USA, 2002.

[160] J. C. Lynch, J. M. Brannon, and J. J. Delfino, "Effects of component interactions on the aqueous solubilities and dissolution rates of the explosive formulations octol, composition B, and LX-14," Journal of Chemical and Engineering Data, vol. 47, no. 3, pp. 542-549, 2002.

[161] J. C. Lynch, "Dissolution kinetics of high explosive compounds (TNT, RDX, HMX),” ERDC/EL TR-02-23, US Army Engineering Research and Development Center, Vicksburg, Miss, USA, 2002. 
[162] J. C. Lynch, K. F. Myers, J. M. Brannon, and J. J. Delfino, "Effects of $\mathrm{pH}$ and temperature on the aqueous solubility and dissolution rate of 2,4,6-trinitrotoluene (TNT), hexahydro1,3,5-trinitro-1,3,5-triazine (RDX), and octahydro-1,3,5,7tetranitro-1,3,5,7-tetrazocine (HMX)," Journal of Chemical and Engineering Data, vol. 46, no. 6, pp. 1549-1555, 2001.

[163] J. H. Lever, S. Taylor, L. Perovich, K. Bjella, and B. Packer, "Dissolution of composition B detonation residuals," Environmental Science and Technology, vol. 39, no. 22, pp. 8803 8811, 2005.

[164] J. C. Lynch, J. M. Brannon, and J. J. Delfino, "Dissolution rates of three high explosive compounds: TNT, RDX, and HMX," Chemosphere, vol. 47, no. 7, pp. 725-734, 2002.

[165] J. C. Lynch, J. M. Brannon, K. Hatfield, and J. J. Delfino, "An exploratory approach to modeling explosive compound persistence and flux using dissolution kinetics," Journal of Contaminant Hydrology, vol. 66, no. 3-4, pp. 147-159, 2003.

[166] J. C. Pennington and J. M. Brannon, "Environmental fate of explosives," Thermochimica Acta, vol. 384, no. 1-2, pp. 163 $172,2002$.

[167] S. B. Haderlein, K. W. Weissmahr, and R. P. Schwarzenbach, "Specific adsorption of nitroaromatic explosives and pesticides to clay minerals," Environmental Science and Technology, vol. 30, no. 2, pp. 612-622, 1996.

[168] K. A. Thorn, J. C. Pennington, and C. A. Hayes, " ${ }^{15} \mathrm{~N}$ NMR investigation of the reduction and binding of TNT in an aerobic bench scale reactor simulating windrow composting," Environmental Science and Technology, vol. 36, no. 17, pp. 3797-3805, 2002.

[169] H. Yamamoto, M. C. Morley, G. E. Speitel, and J. Clausen, "Fate and transport of high explosives in a sandy soil: adsorption and desorption," Soil and Sediment Contamination, vol. 13, no. 5, pp. 459-477, 2004.

[170] J. L. Clausen, C. Scott, and I. Osgerby, "Fate of nitroglycerin and dinitrotoluene in soil at small arms training ranges," Soil and Sediment Contamination, vol. 20, pp. 649-671, 2011.

[171] M. Windholz, The Merck Index, Merck and Company, Rahway, NJ, USA, 9th edition, 1979.

[172] J. Singh, S. D. Comfort, L. S. Hundal, and P. J. Shea, "Longterm RDX sorption and fate in soil," Journal of Environmental Quality, vol. 27, no. 3, pp. 572-577, 1998.

[173] J. C. Pennington and W. H. Patrick Jr., "Adsorption and desorption of 2,4,6-trinitrotoluene by soils," Journal of Environmental Quality, vol. 19, no. 3, pp. 559-567, 1990.

[174] J. M. Brannon, C. B. Price, C. Hayes, and S. L. Yost, "Aquifer soil cation substitution and adsorption of TNT, RDX, and HMX," Soil and Sediment Contamination, vol. 11, no. 3, pp. 327-338, 2002.

[175] C. J. McGrath, "Review of formulations for processes affecting the subsurface transport of explosives," Tech. Rep. IRRP95-2, US Army Corps of Engineers, Waterways Experiment Station, Vicksburg, Miss, USA, 1995.

[176] S. K. Xue, I. K. Iskandar, and H. M. Selim, "Adsorptiondesorption of 2,4,6-trinitrotoluene and hexahydro-1,3,5trinitro-1,3,5-triazine in soils," Soil Science, vol. 160, no. 5, pp. 317-327, 1995.

[177] J. C. Pennington, D. Gunnison, D. W. Harrelson et al., "Natural attenuation of explosives in soil and water systems at Department of Defence sites: interim report," Tech. Rep. EL-99-8, US Army Corps of Engineers, Waterways Experiment Station, Vicksburg, Miss, USA, 1999.
[178] T. E. Myers, J. M. Brannon, J. C. Pennington et al., "Laboratory studies of soil sorption/transformation of TNT, RDX, and HMX," Tech. Rep. IRRP-98-8, US Army Engineer Waterways Experiment Station, Vicksburg, Miss, USA, 1998.

[179] H. M. Selim and I. K. Iskandar, "Sorption-desorption and transport of TNT and RDX in soils," CRREL Report 94-7, US Army Cold Regions Research and Engineering Laboratory, Hanover, NH, USA, 1994.

[180] C. C. Ainsworth, S. D. Harvey, J. E. Szecsodt et al., "Relationship between the leachability characteristics of unique energetic compounds and soil properties," Project 91PP1800, US Army Biomedical Research and Development Laboratory, Fort Detrick, Md, USA, 1993.

[181] C. B. Price, J. M. Brannon, S. L. Yost et al., "Transformation of RDX and HMX under controlled Eh/pH conditions," Tech. Rep. IRRP-98-2, US Army Engineering Waterways Experimental Station, Vicksburg, Miss, USA, 1998.

[182] J. Brannon, P. Deliman, C. Ruiz et al., "Conceptual model and process descriptor formulations for fate and transport of UXO,” Tech. Rep. IRRP-99-1, US Army Engineer Research and Development Center, Vicksburg, Miss, USA, 1999.

[183] T. W. Sheremata, S. Thiboutot, G. Ampleman, L. Paquet, A. Halasz, and J. Hawari, "Fate of 2,4,6-trinitrotoluene and its metabolites in natural and model soil systems," Environmental Science and Technology, vol. 33, no. 22, pp. 4002-4008, 1999.

[184] C. B. Price, J. M. Brannon, S. L. Yost, and A. H. Charolett, "Adsorption and transformation of explosives in low-carbon aquifer soils," Report ERDC/EL TR-00-11, US Army Corps of Engineers, Engineer Research and Development Center, Vicksburg, Miss, USA, 2000.

[185] M. V. Cattaneo, J. C. Pennington, J. M. Brannon, D. Gunnison, D. W. Harrelson, and M. Zakikhani, "Natural attenuation of explosives," in Remediation of Hazardous Waste Contaminated Soils, Marcel Dekker, New York, NY, USA, 2000.

[186] N. Singh, D. Hennecke, J. Hoerner, W. Koerdel, and A. Schaeffer, "Sorption-desorption of trinitrotoluene in soils: effect of saturating metal cations," Bulletin of Environmental Contamination and Toxicology, vol. 80, no. 5, pp. 443-446, 2008.

[187] K. W. Weissmahr, S. B. Haderlein, and R. P. Schwarzenbach, "Complex formation of soil minerals with nitroaromatic explosives and other $\pi$-acceptors," Soil Science Society of America Journal, vol. 62, no. 2, pp. 369-378, 1998.

[188] J. M. Brannon, C. B. Price, S. L. Yost, C. Hayes, J. E. Mirecki, and B. Porter, "Fate and transport parameters for firing range residues," In Distribution and Fate of Energetics on DoD Test and Training Ranges: Interim Report 4 ERDC TR-044, US Army Engineer Research and Development Center, Vicksburg, Miss, USA, 2004.

[189] W. R. Haag, R. Spanggord, T. Mill et al., "Aquatic environmental fate of nitroguanidine," Environmental Toxicology and Chemistry, vol. 9, no. 11, pp. 1359-1367, 1990.

[190] J. L. Clausen, C. Scott, N. Mulherin et al., "Sorption/desorption measurements of nitroglycerin and dinitrotoluene in Camp Edwards, Massachusetts soil," ERDC/CRREL TR-101, Cold Regions Research and Engineering Laboratory, US Army Engineer Research and Development Center, Hanover, NH, USA, 2010.

[191] G. Ji and X. Kong, "Adsorption of chloride, nitrate, and perchlorate by variable charge soils," Pedosphere, vol. 2, pp. 317-326, 1992. 
[192] F. Monteil-Rivera, C. Groom, and J. Hawari, "Sorption and degradation of octahydro-1,3,5,7-tetranitro-1,3,5,7tetrazocine in soil," Environmental Science and Technology, vol. 37, no. 17, pp. 3878-3884, 2003.

[193] C. B. Price, J. M. Brannon, and C. A. Hayes, "Effect of redox potential and $\mathrm{pH}$ on TNT transformation in soil-water slurries," Journal of Environmental Engineering, vol. 123, no. 10, pp. 988-992, 1997.

[194] T. A. Douglas, M. E. Walsh, C. J. McGrath, and C. A. Weiss, "Investigating the fate of nitroaromatic (TNT) and nitramine (RDX and HMX) explosives in fractured and pristine soils," Journal of Environmental Quality, vol. 38, no. 6, pp. 22852294, 2009.

[195] D. J. Glover and J. C. Hoffsommer, "Photolysis of RDX. Identification and reactions of products," Tech. Rep. NSWC TR-79-349, Naval Surface Weapons Center, Silver Spring, Md, USA, 1979.

[196] N. E. Burlinson, L. A. Kaplan, and C. E. Adams, "Photochemistry of TNT: investigation of the "pink water" problem," NOLTR 73-172, Naval Ordnance Laboratory, Silver Spring, Md, USA, 1973.

[197] M. Godejohann, A. Preiss, K. Levsen, K.-M. Wollin, and C. Mügge, "Determination of polar organic pollutants in aqueous samples of former ammunition sites in Lower Saxony by means of HPLC/photodiode array detection (HPLC/PDA) and proton nuclear magnetic resonance spectroscopy $\left({ }^{1} \mathrm{H}\right.$ NMR)," Acta Hydrochimica et Hydrobiologica, vol. 26, no. 6, pp. 330-337, 1998.

[198] T. C. Schmidt, M. Petersmann, L. Kaminski, E. V. Löw, and G. Stork, "Analysis of aminobenzoic acids in waste water from a former ammunition plant with HPLC and combined diode array and fluorescence detection," Fresenius' Journal of Analytical Chemistry, vol. 357, no. 1, pp. 121-126, 1997.

[199] A. Preiss, M. Elend, S. Gerling, E. Berger-Preiss, and K. Steinbach, "Identification of highly polar nitroaromatic compounds in leachate and ground water samples from a TNTcontaminated waste site by LC-MS, LC-NMR, and off-line NMR and MS investigations," Analytical and Bioanalytical Chemistry, vol. 389, no. 6, pp. 1979-1988, 2007.

[200] D. Hennecke, W. Kördel, K. Steinbach, and B. Herrmann, "Transformation processes of explosives in natural water/sediment systems," in Proceedings of the 10th International UFZ Deltares/TNO Conference on Management of Soil, Groundwater and Sediments, Milano, Italy, September 2008.

[201] D. T. Burton and S. D. Turley, "Reduction of hexahydro1,3,5-trinitro-1,3,5-triazine (RDX) toxicity to the cladoceran Ceriodaphnia dubia following photolysis in sunlight," Bulletin of Environmental Contamination and Toxicology, vol. 55, no. 1, pp. 89-95, 1995.

[202] P. Bose, W. H. Glaze, and D. S. Maddox, "Degradation of RDX by various advanced oxidation processes: II. organic by-products," Water Research, vol. 32, no. 4, pp. 1005-1018, 1998.

[203] G. R. Peyton, M. H. LeFaivre, and S. W. Maloney, "Verification of RDX photolysis mechanism," Report CERL-TR99/93, Construction Engineering Research Lab (Army), IL, 1999.

[204] H. M. Seth-Smith, Microbial degradation of RDX, PhD Dissertation, University of Cambridge, UK, 2002.

[205] M. S. Simmons and R. G. Zepp, "Influence of humic substances on photolysis of nitroaromatic compounds in aqueous systems," Water Research, vol. 20, no. 7, pp. 899-904, 1986.
[206] A. Mills, A. Seth, and G. Peters, "Alkaline hydrolysis of trinitrotoluene, TNT," Physical Chemistry Chemical Physics, vol. 5, no. 18, pp. 3921-3927, 2003.

[207] J. L. Davis, M. C. Brooks, S. L. Larson, C. C. Nestler, and D. R. Felt, "Lime treatment of explosives-contaminated soil from munitions plants and firing ranges," Soil and Sediment Contamination, vol. 15, no. 6, pp. 565-580, 2006.

[208] M. Emmrich, "Kinetics of the alkaline hydrolysis of 2,4,6trinitrotoluene in aqueous solution and highly contaminated soils," Environmental Science and Technology, vol. 33, no. 21, pp. 3802-3805, 1999.

[209] A. Saupe, H. J. Garvens, and L. Heinze, "Alkaline hydrolysis of TNT and TNT in soil followed by thermal treatment of the hydrolysates," Chemosphere, vol. 36, no. 8, pp. 1725-1744, 1998.

[210] R. Bajpai, D. Parekh, S. Herrmann, M. Popović, J. Paca, and M. Qasim, "A kinetic model of aqueous-phase alkali hydrolysis of 2,4,6-trinitrotoluene," Journal of Hazardous Materials, vol. 106, no. 1, pp. 37-44, 2004.

[211] R. J. Spanggord, T. Mill, T. W. Chou, R. W. Mabey, J. H. Smith, and S. Lee, "Environmental fate studies on certain munition wastewater constituents," Final Report, Phase 1: Literature Review LSU-7934, SRI International, Menlo Park, Calif, USA, 1980.

[212] R. J. Spanggord, R. W. Mabey, T. W. Chou et al., "Environmental fate studies of HMX, screening studies, final report, phase I-Laboratory study," SRI Project LSU-4412, SRI International, Menlo Park, CA, for US Army Medical Research and Development Command, Fort Detrick, Md, USA, 1982.

[213] V. K. Balakrishnan, A. Halasz, and J. Hawari, "Alkaline hydrolysis of the cyclic nitramine explosives RDX, HMX, and CL-20: new insights into degradation pathways obtained by the observation of novel intermediates," Environmental Science and Technology, vol. 37, pp. 1838-1843, 2003.

[214] K. B. Gregory, P. Larese-Casanova, G. F. Parkin, and M. M. Scherer, "Abiotic transformation of hexahydro-1,3,5-trinito1,3,5-triazine by Fe II bound to magnetite," Environmental Science and Technology, vol. 38, no. 5, pp. 1408-1414, 2004.

[215] D. M. Townsend, T. E. Myers, and D. D. Adrian, "2,4,6trinitrotoluene (TNT) transformation/sorption in thin-disk soil columns," Tech. Rep. IRRP-95-4, US Army Engineer Waterways Experiment Station, Vicksburg, Miss, USA, 1995.

[216] H. M. Selim, S. K. Xue, and I. K. Iskandar, "Transport of 2,4,6-trinitrotoluene and hexahydro-1,3,5-trinitro-1,3,5triazine in soils," Soil Science, vol. 160, no. 5, pp. 328-339, 1995.

[217] D. L. Kaplan and A. M. Kaplan, "Thermophilic biotransformations of 2,4,6-trinitrotoluene under simulated composting conditions," Applied and Environmental Microbiology, vol. 44, no. 3, pp. 757-760, 1982.

[218] N. G. McCormick, F. E. Feeherry, and H. S. Levinson, "Microbial transformation of 2,4,6-trinitrotoluene and other nitroaromatic compounds," Applied and Environmental Microbiology, vol. 31, no. 6, pp. 949-958, 1976.

[219] C. B. Price, J. M. Brannon, and C. A. Hayes, "Transformation of 2,4,6-trinitrotoluene under controlled $\mathrm{Eh} / \mathrm{pH}$ conditions," Tech. Rep. IRRP-95-5, US Army Engineer Waterways Experiment Station, Vicksburg, Miss, USA, 1995.

[220] R. G. Reifler and B. F. Smets, "Enzymatic reduction of 2,4,6trinitrotoluene and related nitroarenes: kinetics linked to one-electron redox potentials," Environmental Science and Technology, vol. 34, no. 18, pp. 3900-3906, 2000. 
[221] J. Z. Bandstra, R. Miehr, R. L. Johnson, and P. G. Tratnyek, "Reduction of 2,4,6-trinitrotoluene by iron metal: kinetic controls on product distributions in batch experiments," Environmental Science and Technology, vol. 39, no. 1, pp. 230 238, 2005.

[222] J. F. Devlin, J. Klausen, and R. P. Schwarzenbach, "Kinetics of nitroaromatic reduction on granular iron in recirculating batch experiments," Environmental Science and Technology, vol. 32, no. 13, pp. 1941-1947, 1998.

[223] J. M. Brannon, C. B. Price, and C. Hayes, "Abiotic transformation of TNT in montmorillonite and soil suspensions under reducing conditions," Chemosphere, vol. 36, no. 6, pp. 1453-1462, 1998.

[224] R. L. Crawford, "Biodegradation of nitrated munitions compounds and herbicides by obligately anaerobic bacteria," in Biodegradation of Nitroaromatic Compounds, J. C. Spain, Ed., Plenum Press, New York, NY, USA, 1995.

[225] S. B. Funk, D. J. Roberts, D. L. Crawford, and R. L. Crawford, "Initial-phase optimization for bioremediation of munition compound-contaminated soils," Applied and Environmental Microbiology, vol. 59, no. 7, pp. 2171-2177, 1993.

[226] C. B. Price, J. M. Brannon, S. L. Yost, and C. A. Hayes, "Relationship between redox potential and $\mathrm{pH}$ on RDX transformation in soil-water slurries," Journal of Environmental Engineering, vol. 127, no. 1, pp. 26-31, 2001.

[227] N. G. McCormick, J. H. Cornell, and A. M. Kaplan, "Biodegradation of hexahydro-1,3,5-trinitro-1,3,5-triazine," Applied and Environmental Microbiology, vol. 42, no. 5, pp. 817-823, 1981.

[228] D. L. Kaplan, "Biotechnology and bioremediation for organic energetic compounds," in Organic Energetic Compounds, P. Marikas, Ed., pp. 373-395, Nova Science Publishers, New York, NY, USA, 1996.

[229] J. Park, S. D. Comfort, P. J. Shea, and T. A. Machacek, "Remediating munitions-contaminated soil with zero valent iron and cationic surfactants," Journal of Environmental Quality, vol. 33, no. 4, pp. 1305-1313, 2004.

[230] L. S. Hundal, J. Singh, E. L. Bier, P. J. Shea, S. D. Comfort, and W. L. Powers, "Removal of TNT and RDX from water and soil using iron metal," Environmental Pollution, vol. 97, no. 1-2, pp. 55-64, 1997.

[231] D. Colon, E. J. Weber, J. L. Anderson, P. Winget, and L. A. Suarez, "Reduction of nitrosobenzenes and n-hydroxylanilines by $\mathrm{Fe}(\mathrm{II})$ species: elucidation of the reaction mechanism," Environmental Science and Technology, vol. 40, pp. 4449-4454, 2006.

[232] D. Liu, K. Thomson, and A. C. Anderson, "Identification of nitroso compounds from biotransformation of 2,4-dinitrotoluene," Applied and Environmental Microbiology, vol. 47, no. 6, pp. 1295-1298, 1984.

[233] J. S. Zhao, D. Fournier, S. Thiboutot, G. Ampleman, and J. Hawari, "Biodegradation and bioremediation of explosives," in Applied Bioremediation and Phytoremediation, A. Singh and O. P. Ward, Eds., Springer, New York, NY, USA, 2004.

[234] M. B. Pasti-Grigsby, A. Paszczynski, S. Goszczynski, D. L. Crawford, and R. L. Crawford, "Influence of aromatic substitution patterns on azo dye degradability by Streptomyces spp. and Phanerochaete chrysosporium," Applied and Environmental Microbiology, vol. 58, no. 11, pp. 3605-3613, 1992.

[235] J. T. Spadaro, M. H. Gold, and V. Renganathan, "Degradation of azo dyes by the lignin-degrading fungus Phanerochaete chrysosporium," Applied and Environmental Microbiology, vol. 58, no. 8, pp. 2397-2401, 1992.
[236] G. Soli, "Microbial degradation of cyclonite (RDX)," Report NWC-TP-5525 / AD-762 751, US National Technical Information Service (Naval Weapons Center China Lake CA), Washington, DC, USA, 1973.

[237] R. J. Spanggord, T. Mill, T. W. Chou, R. W. Mabey, W. H. Smith, and S. Lee, "Environmental fate studies on certain munition wastewater constituents, final report, part IIlaboratory study," AD A099256, SRI International, Menlo Park, CA, for US Army Medical Research and Development Command, Fort Detrick, Md, USA, 1980.

[238] N. V. Coleman, D. R. Nelson, and T. Duxbury, "Aerobic biodegradation of hexahydro-1,3,5 trinitro-1,3,5-triazine (RDX) as a nitrogen source by a Rhodococcus sp., strain DN22," Soil Biology and Biochemistry, vol. 30, no. 8-9, pp. 1159-1167, 1998.

[239] N. G. McCormick, J. H. Cornell, and A. M. Kaplan, "The anaerobic transformation of RDX and HMX and their acetylated derivatives," Tech. Rep. A149464 (TR85-008), US Army Natick Research and Development Center, Natick, Mass, USA, 1985.

[240] K. M. Regan and R. L. Crawford, "Characterization of Clostridium bifermentans and its biotransformation of 2,4,6-trinitrotoluene (TNT) and 1,3,5-triaza-1,3,5-trinitrocyclohexane (RDX)," Biotechnology Letters, vol. 16, no. 10, pp. 1081-1086, 1994.

[241] C. A. Groom, S. Beaudet, A. Halasz, L. Paquet, and J. Hawari, "Detection of the cyclic nitramine explosives hexahydro1,3,5-trinitro-1,3,5-triazine (RDX) and octahydro-1,3,5,7tetranitro-1,3,5,7-tetrazine (HMX) and their degradation products in soil environments," Journal of Chromatography A, vol. 909, no. 1, pp. 53-60, 2001.

[242] C. F. Shen, J. A. Hawari, L. Paquet, G. Ampleman, S. Thiboutot, and S. R. Guiot, "Explosive biodegradation in soil slurry batch reactors amended with exogenous microorganisms," Water Science and Technology, vol. 43, no. 3, pp. 291298, 2001.

[243] C. F. Shen, S. R. Guiot, S. Thiboutot, G. Ampleman, and J. Hawari, "Fate of explosives and their metabolites in bioslurry treatment processes," Biodegradation, vol. 8, no. 5, pp. 339347, 1997.

[244] S. Toze and L. Zappia, "Microbial degradation of munition compounds in production wastewater," Water Research, vol. 33, no. 13, pp. 3040-3045, 1999.

[245] D. L. Freedman and K. W. Sutherland, "Biodegradation of hexahydro-1,3,5-trinitro-1,3,5-triazine (RDX) under nitrate-reducing conditions," Water Science and Technology, vol. 38, no. 7, pp. 33-40, 1998.

[246] R. Boopathy, M. Gurgas, J. Ullian, and J. F. Manning, "Metabolism of explosive compounds by sulfate-reducing bacteria," Current Microbiology, vol. 37, no. 2, pp. 127-131, 1998.

[247] R. Boopathy, J. Manning, and C. F. Kulpa, "Biotransformation of explosives by anaerobic consortia in liquid culture and in soil slurry," International Biodeterioration and Biodegradation, vol. 41, no. 1, pp. 67-74, 1998.

[248] J. Hawari, A. Halasz, T. Sheremata et al., "Characterization of metabolites during biodegradation of hexahydro1,3,5-trinitro-1,3,5-triazine (RDX) with municipal anaerobic sludge," Applied and Environmental Microbiology, vol. 66, no. 6, pp. 2652-2657, 2000.

[249] C. L. Kitts, D. P. Cunningham, and P. J. Unkefer, "Isolation of three hexahydro-1,3,5-trinitro-1,3,5-triazine-degrading species of the family Enterobacteriaceae from nitramine 
explosive contaminated soil," Applied and Environmental Microbiology, vol. 60, no. 12, pp. 4608-4711, 1994.

[250] D. M. Young, P. J. Unkefer, and K. L. Ogden, "Biotransformation of hexahydro-1,3,5-trinitro-1,3,5-triazine (RDX) by a prospective consortium and its most effective isolate Serratia marcescens," Biotechnology and Bioengineering, vol. 53, pp. 515-522, 1997.

[251] T. W. Sheremata and J. Hawari, "Mineralization of RDX by the white rot fungus Phanerochaete chrysosporium to carbon dioxide and nitrous oxide," Environmental Science and Technology, vol. 34, no. 16, pp. 3384-3388, 2000.

[252] P. R. Binks, S. Nicklin, and N. C. Bruce, "Degradation of hexahydro-1,3,5-trinitro-1,3,5-triazine (RDX) by Stenotrophomonas maltophilia PB1," Applied and Environmental Microbiology, vol. 61, no. 4, pp. 1318-1322, 1995.

[253] B. Bhushan, A. Halasz, S. Thiboutot, G. Ampleman, and J. Hawari, "Chemotaxis-mediated biodegradation of cyclic nitramine explosives RDX, HMX, and CL-20 by Clostridium sp. EDB2," Biochemical and Biophysical Research Communications, vol. 316, no. 3, pp. 816-821, 2004.

[254] Y. Yang, X. Wang, P. Yin, W. Li, and P. Zhou, "Studies on three strains of Corynebacterium degrading cyclotrimethylenetrinitroamine (RDX)," Acta Microbiologica Sinica, vol. 23, pp. 251-256, 1983.

[255] S. Thiboutot, J. Lavigne, G. Ampleman et al., The International Symposium on Energetic Materials Technology, Orlando, Fla, USA, 1994.

[256] A. M. Jones, S. Labelle et al., "Assessment of the aerobic biodegradation potential of RDX, TNT, GAP, and NC," in Environmental Biotechnology - Principles and Applications, M. Moo-Young, W. A. Anderson, and A. M. Chakrabarty, Eds., pp. 368-381, Kluwer Academic Press, New York, NY, USA, 1995.

[257] B. van Aken, J. M. Yoon, C. L. Just, and J. L. Schnoor, "Metabolism and mineralization of hexahydro-1,3,5-trinitro-1,3,5triazine inside poplar tissues (Populus deltodes $p \times$ nigra DN34)," Environmental Science and Technology, vol. 38, no. 17, pp. 4572-4579, 2004.

[258] C. Axtell, C. G. Johnston, and J. A. Bumpus, "Bioremediation of soil contaminated with explosives at the Naval Weapons Station Yorktown," Soil and Sediment Contamination, vol. 9, no. 6, pp. 537-548, 2000.

[259] D. Fournier, A. Halasz, S. Thiboutot, G. Ampleman, D. Manno, and J. Hawari, "Biodegradation of octahydro1,3,5,7-tetranitro-1,3,5,7-tetrazocine (HMX) by Phanerochaete chrysosporium: new insight into the degradation pathway," Environmental Science and Technology, vol. 38, no. 15, pp. 4130-4133, 2004.

[260] J. S. Zhao, J. Spain, and J. Hawari, "Phylogenetic and metabolic diversity of hexahydro-1,3,5-trinitro-1,3,5- triazine (RDX)-transforming bacteria in strictly anaerobic mixed cultures enriched on RDX as nitrogen source," FEMS Microbiology Ecology, vol. 46, no. 2, pp. 189-196, 2003.

[261] R. Boopathy, "Enhanced biodegradation of cyclotetramethylenetetranitramine (HMX) under mixed electron-acceptor condition," Bioresource Technology, vol. 76, no. 3, pp. 241244, 2001.

[262] A. Haïdour and J. L. Ramos, "Identification of products resulting from the biological reduction of 2,4,6-trinitrotoluene, 2,4-dinitrotoluene, and 2,6-dinitrotoluene by Pseudomonas sp.", Environmental Science and Technology, vol. 30, no. 7, pp. 2365-2370, 1996.
[263] U. Lendenmann, J. C. Spain, and B. F. Smets, "Simultaneous biodegradation of 2,4-dinitrotoluene and 2,6-dinitrotoluene in an aerobic fluidized-bed biofilm reactor," Environmental Science and Technology, vol. 32, no. 1, pp. 82-87, 1998.

[264] S. F. Nishino, G. Paoli, and J. C. Spain, "Aerobic biodegradation of dinitrotoluenes and pathway for bacterial degradation of 2,6-dinitrotoluene," Applied and Environmental Microbiology, vol. 66, pp. 2138-2147, 2000.

[265] N. G. McCormick, J. H. Cornell, and A. M. Kaplan, "Identification of biotransformation products from 2,4 dinitrotoluene," Applied and Environmental Microbiology, vol. 35, no. 5, pp. 945-948, 1978.

[266] K. F. Reardon and J. C. Spain, "Immobilized cell bioreactor for 2,4-dinitrotoluene degradation," in Proceedings of the ABSTR Biot86, 205th ACS National Meeting, American Chemical Society, Washington, DC, USA, 1993.

[267] R. E. Williams and N. C. Bruce, "The role of nitrate ester reductase enzymes in the biodegradation of explosives," in Biodegradation of Nitroaromatic Compounds and Explosives, J. C. Spain, J. B. Hughes, and H.-J. Knackmuss, Eds., Lewis Publishers, Boca Raton, Fla, USA, 2000.

[268] G. F. White, J. R. Snape, and S. Nicklin, "Biodegradation of glycerol trinitrate and pentaerythritol tetranitrate by Agrobacterium radiobacter," Applied and Environmental Microbiology, vol. 62, no. 2, pp. 637-642, 1996.

[269] M. Meng, W. Q. Sun, L. A. Goelhaar et al., "Denitration of glycerol trinitrate by resting cells and cell extracts of Bacillus thuringiensis/cereus and Enterobacter agglemerans," Applied and Environmental Microbiology, vol. 61, no. 7, pp. 25482553, 1995.

[270] T. M. Wendt, J. H. Cornell, and A. M. Kaplan, "Microbial degradation of glycerol nitrates," Applied and Environmental Microbiology, vol. 36, no. 5, pp. 693-699, 1978.

[271] S. Bhaumik, C. Christodoulatos, G. P. Korfiatis, and B. W. Brodman, "Aerobic and anaerobic biodegradation of nitroglycerin in batch and packed bed bioreactors," Water Science and Technology, vol. 36, no. 2-3, pp. 139-146, 1997.

[272] C. Christodoulatos, S. Bhaumik, and B. W. Brodman, "Anaerobic biodegradation of nitroglycerin," Water Research, vol. 31, no. 6, pp. 1462-1470, 1997.

[273] C. E. French, S. Nicklin, and N. C. Bruce, "Sequence and properties of pentaerythritol tetranitrate reductase from Enterobacter cloacae PB2," Journal of Bacteriology, vol. 178, no. 22, pp. 6623-6627, 1996.

[274] J. V. Accashian, R. T. Vinopal, B.-J. Kim, and B. F. Smets, "Aerobic growth on nitroglycerin as the sole carbon, nitrogen, and energy source by a mixed bacterial culture," Applied and Environmental Microbiology, vol. 64, no. 9, pp. 3300-3304, 1998.

[275] G. F. White, J. R. Snape, and S. Nicklin, "Bacterial biodegradation of glycerol trinitrate," International Biodeterioration and Biodegradation, vol. 38, no. 2, pp. 77-82, 1996.

[276] D. S. Blehert, B. G. Fox, and G. H. Chambliss, "Cloning and sequence analysis of two Pseudomonas flavoprotein xenobiotic reductases," Journal of Bacteriology, vol. 181, no. 20, pp. 6254-6263, 1999.

[277] J. R. Snape, N. A. Walkley, A. P. Morby, S. Nicklin, and G. F. White, "Purification, properties, and sequence of glycerol trinitrate reductase from Agrobacterium radiobacter," Journal of Bacteriology, vol. 179, no. 24, pp. 7796-7802, 1997.

[278] D. S. Blehert, K. Becker, and G. H. Chambliss, "Isolation and characterization of bacteria that degrade nitroglycerin," in Proceedings of the Tri-Service Environmental Technology 
Workshop. Enhancing Readiness through Environmental Quality Technology, pp. 197-204, Defense Technical Information Center, Hershey, Pa, USA, May 1996, ADP017715.

[279] S. J. Marshall and G. F. White, "Complete denitration of nitroglycerin by bacteria isolated from a washwater soakaway," Applied and Environmental Microbiology, vol. 67, no. 6, pp. 2622-2626, 2001.

[280] S. Yost, Effects of redox potential and $\mathrm{pH}$ on the fate of nitroglycerin in a surface and aquifer soil, M.S. thesis, Louisiana State University, Baton Rouge, La, USA, 2004.

[281] B. van Aken and J. L. Schnoor, "Evidence of perchlorate $\left(\mathrm{ClO}_{4}^{-}\right)$reduction in plant tissues (Poplar tree) using radiolabeled ${ }^{36} \mathrm{ClO}_{4}{ }^{-}$," Environmental Science and Technology, vol. 36, no. 12, pp. 2783-2788, 2002.

[282] G. B. Rikken, A. G. M. Kroon, and C. G. Ginkel, "Transformation of (per)chlorate into chloride by a newly isolated bacterium: reduction and dismutation," Applied Microbiology and Biotechnology, vol. 45, no. 3, pp. 420-426, 1996.

[283] J. D. Coates, U. Michaelidou, R. A. Bruce, S. M. O’Connor, J. N. Crespi, and L. A. Achenbach, "Ubiquity and diversity of dissimilatory (per)chlorate-reducing bacteria," Applied and Environmental Microbiology, vol. 65, no. 12, pp. 5234-5241, 1999.

[284] V. N. Korenkov, V. I. Romanenko, S. I. Kuznetsov, and J. V. Voronnov, "Process for purification of industrial waste waters from perchlorates and chlorates," US patent 3,943,055, 1976.

[285] W. Wallace, T. Ward, A. Breen, and H. Attaway, "Identification of an anaerobic bacterium which reduces perchlorate and chlorate as Wolinella succinogenes," Journal of Industrial Microbiology, vol. 16, no. 1, pp. 68-72, 1996.

[286] R. A. Bruce, L. A. Achenbach, and J. D. Coates, "Reduction of (per)chlorate by a novel organism isolated from paper mill waste," Environmental Microbiology, vol. 1, no. 4, pp. 319329, 1999.

[287] D. C. Herman and W. T. Frankenberger, "Microbialmediated reduction of perchlorate in groundwater," Journal of Environmental Quality, vol. 27, no. 4, pp. 750-754, 1998.

[288] B. E. Logan, H. Zhang, P. Mulvaney, M. G. Milner, I. M. Head, and R. F. Unz, "Kinetics of perchlorate-and chloraterespiring bacteria," Applied and Environmental Microbiology, vol. 67, no. 6, pp. 2499-2506, 2001.

[289] B. C. Okeke, T. Giblin, and W. T. Frankenberger, "Reduction of perchlorate and nitrate by salt tolerant bacteria," Environmental Pollution, vol. 118, no. 3, pp. 357-363, 2002. 

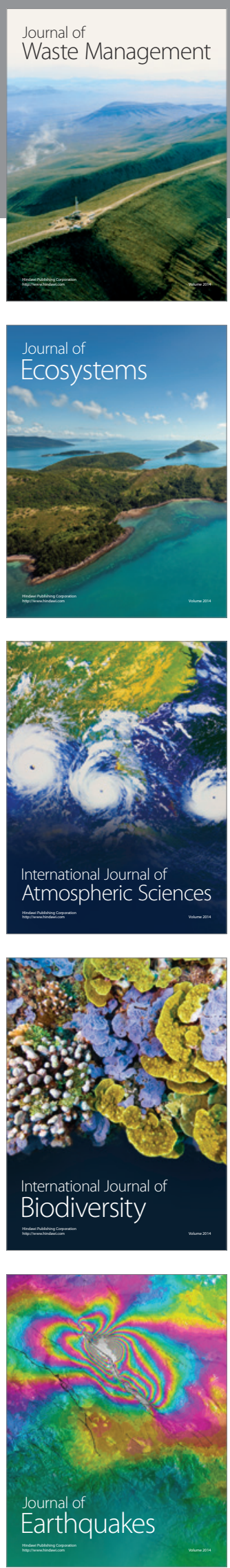
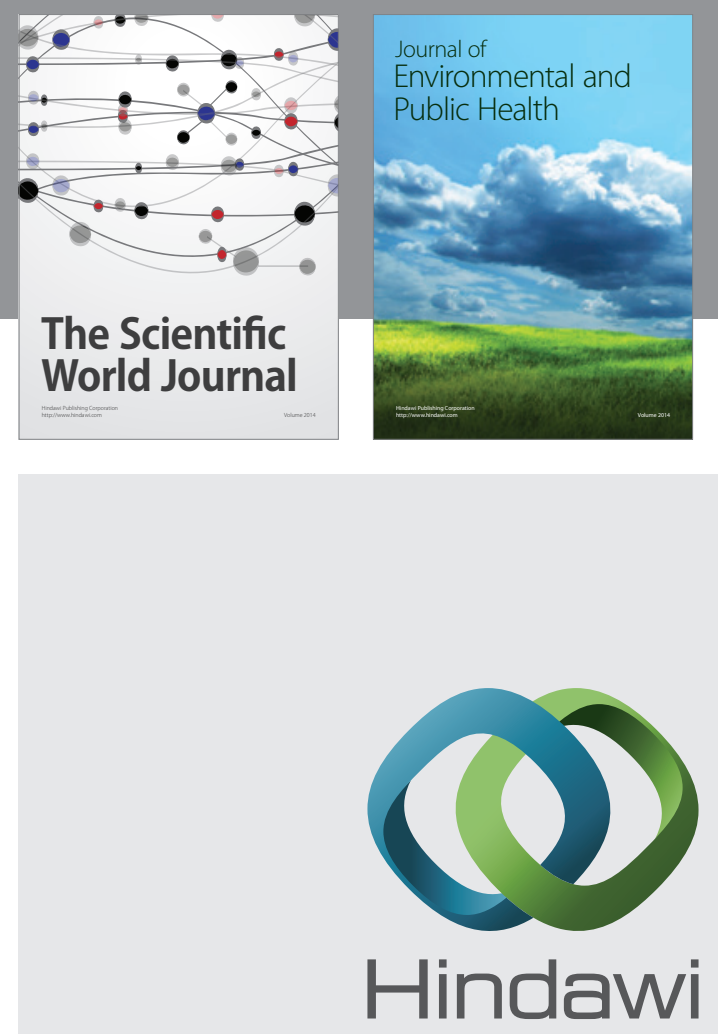

Submit your manuscripts at

http://www.hindawi.com
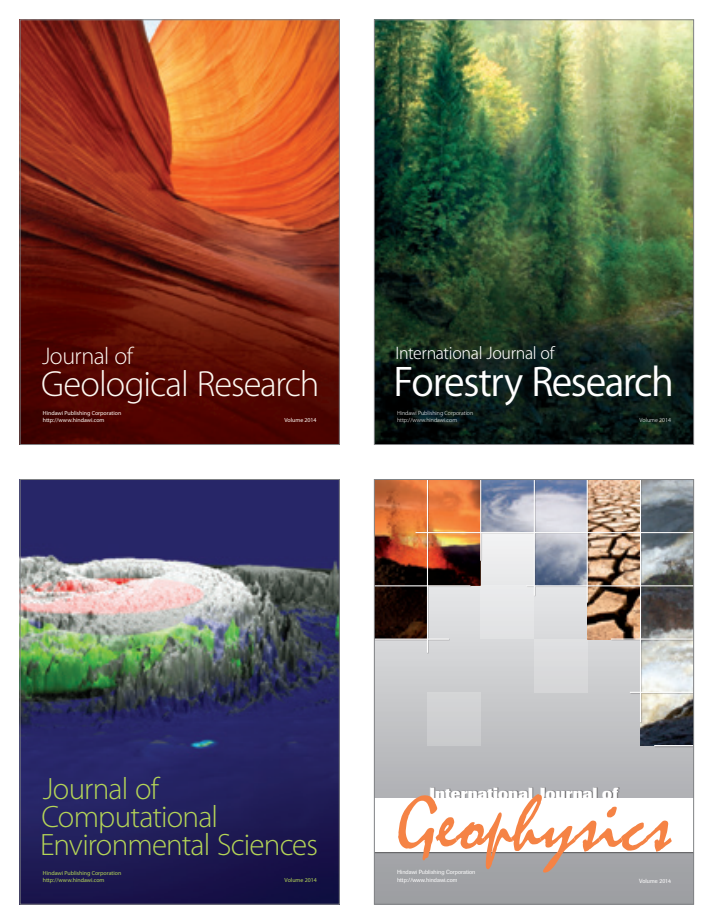
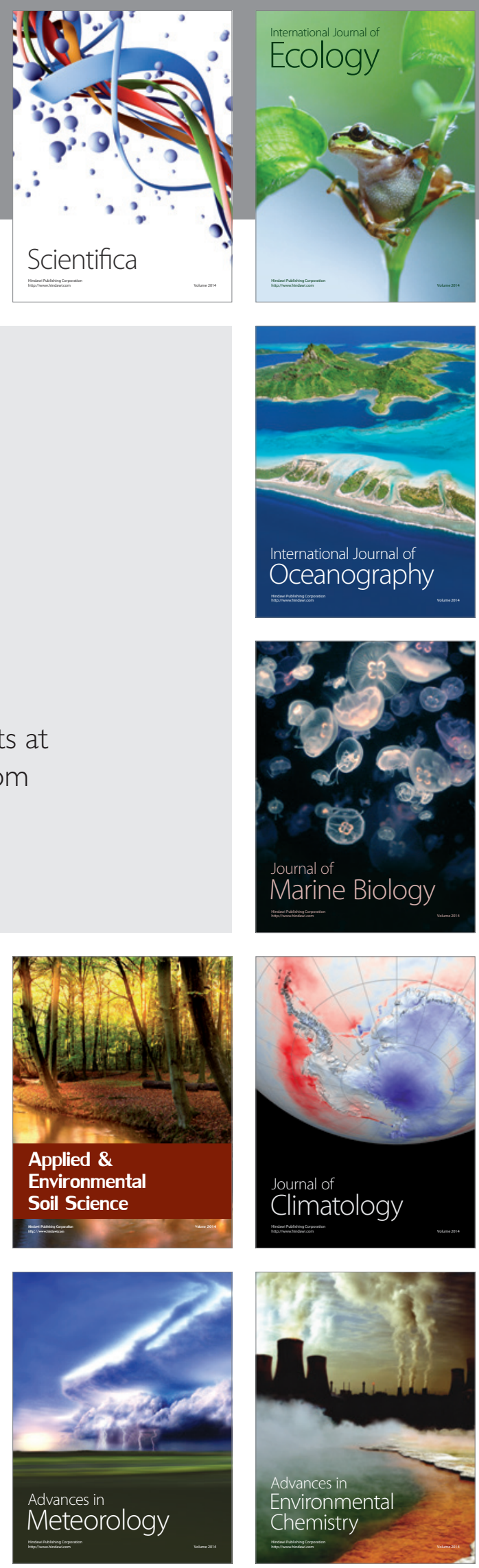